\title{
Induction of multi-antigen multi-stage immune responses against Plasmodium falciparum in rhesus monkeys, in the absence of antigen interference, with heterologous DNA prime/poxvirus boost immunization
}

\author{
George Jiang1,2, Yupin Charoenvit ${ }^{1}$, Alberto Moreno ${ }^{3,4}$, Maria F Baraceros ${ }^{1,2}$, \\ Glenna Banania1,2, Nancy Richie ${ }^{1,2}$, Steve Abot ${ }^{1,2}$, Harini Ganeshan 1,2, \\ Victoria Fallarme ${ }^{1,2}$, Noelle B Patterson ${ }^{1,2}$, Andrew Geall ${ }^{5}$, Walter R Weiss ${ }^{1}$, \\ Elizabeth Strobert ${ }^{4}$, Ivette Caro-Aquilar ${ }^{4}$, David E Lanar ${ }^{6}$, Allan Saul ${ }^{7}$, \\ Laura B Martin7, Kalpana Gowda1, Craig R Morrissette ${ }^{6}$, David C Kaslow ${ }^{5}$, \\ Daniel J Carucci1 ${ }^{1}$, Mary R Galinski ${ }^{3,4}$ and Denise L Doolan*1,8,9
}

Address: ${ }^{1}$ Malaria Program, Naval Medical Research Center, Silver Spring, MD 20910-7500, USA, ${ }^{2}$ Henry M. Jackson Foundation, Rockville, MD 20852, USA, ${ }^{3}$ Emory Vaccine Center, Yerkes National Primate Research Center, Emory University, Atlanta, GA 30329, USA, ${ }^{4}$ Division of Infectious Diseases, Department of Medicine, Emory University School of Medicine, Emory University, Atlanta, GA 30329, USA, 5Vical, Inc., San Diego, CA 92121, USA, ${ }^{6}$ Walter Reed Army Institute of Research, Silver Spring, MD 20910-7500, USA, ${ }^{7}$ Malaria Vaccine Development Branch, National Institute of Allergies and Infectious Diseases, National Institutes of Health, Rockville, MD 20852, USA, ${ }^{8}$ Department of Molecular Microbiology and Immunology, School of Hygiene and Public Health, Johns Hopkins University, Baltimore, MD 21205-2179, USA and ${ }^{9}$ The Queensland Institute of Medical Research, The Bancroft Centre, 300 Herston Road, PO Royal Brisbane Hospital, Brisbane QLD 4029 Australia

Email: George Jiang - jiang_george@bah.com; Yupin Charoenvit - charoenvity@nmrc.navy.mil; Alberto Moreno - amoreno@rmy.emory.edu; Maria F Baraceros - sjs1973maria@yahoo.com; Glenna Banania - bananiag@nmrc.navy.mil; Nancy Richie - Nancy.Richie@amedd.army.mil; Steve Abot - abots@nmrc.navy.mil; Harini Ganeshan - ganeshanh@nmrc.navy.mil; Victoria Fallarme - fallarmev@nmrc.navy.mil; Noelle B Patterson - pattersonn@nmrc.navy.mil; Andrew Geall - andrew.geall@novartis.com; Walter R Weiss - weissw@nmrc.navy.mil; Elizabeth Strobert - estrobert@rmy.emory.edu; Ivette Caro-Aquilar - icaroaquilar@rmy.emory.edu; David E Lanar - david.lanar@us.army.mil; AllanSaul - asaul@niaid.nih.gov; Laura B Martin - lmartin@niaid.nih.gov; Kalpana Gowda - gowdak@nmrc.navy.mil; Craig R Morrissette - craig.morrissette@us.army.mil; David C Kaslow - David_Kaslow@merck.com; Daniel J Carucci - dcarucci@fnih.org; Mary R Galinski - Galinski@rmy.emory.edu; Denise L Doolan* - Denise.Doolan@qimr.edu.au

* Corresponding author

Published: 9 October 2007

Malaria Journal 2007, 6:135

doi:10.1 186/1475-2875-6-135
Received: 15 July 2007

Accepted: 9 October 2007

(C) 2007 Jiang et al; licensee BioMed Central Ltd.

This is an Open Access article distributed under the terms of the Creative Commons Attribution License (http://creativecommons.org/licenses/by/2.0), which permits unrestricted use, distribution, and reproduction in any medium, provided the original work is properly cited.

\begin{abstract}
The present study has evaluated the immunogenicity of single or multiple Plasmodium falciparum (Pf) antigens administered in a DNA prime/poxvirus boost regimen with or without the poloxamer CRLI005 in rhesus monkeys. Animals were primed with PfCSP plasmid DNA or a mixture of PfCSP, PfSSP2/TRAP, PfLSAI, PfAMAI and PfMSPI-42 (CSLAM) DNA vaccines in PBS or formulated with CRLI005, and subsequently boosted with ALVAC-Pf7, a canarypox virus expressing the CSLAM antigens. Cell-mediated immune responses were evaluated by IFN- $\gamma$ ELIspot and intracellular cytokine staining, using recombinant proteins and overlapping synthetic peptides. Antigen-specific and parasite-specific antibody responses were evaluated by ELISA and IFAT, respectively. Immune responses to all components of the multi-antigen mixture were demonstrated following immunization with either DNA/PBS or DNA/CRLI005, and no antigen
\end{abstract}


interference was observed in animals receiving CSLAM as compared to PFCSP alone. These data support the down-selection of the CSLAM antigen combination. CRLI005 formulation had no apparent effect on vaccine-induced $T$ cell or antibody responses, either before or after viral boost. In high responder monkeys, CD4+IL-2+ responses were more predominant than CD8+ $\mathrm{T}$ cell responses. Furthermore, CD8+ IFN- $\gamma$ responses were detected only in the presence of detectable CD4+ T cell responses. Overall, this study demonstrates the potential for multivalent $P f$ vaccines based on rational antigen selection and combination, and suggests that further formulation development to increase the immunogenicity of DNA encoded antigens is warranted.

\section{Background}

Despite intense research efforts, malaria remains a significant public health problem [1] and is associated with significant constraints on economic progress and productivity [2] in the developing world. Especially with the spread of drug-resistant Plasmodium parasites and insecticide-resistant Anopheles vectors, development of an effective malaria vaccine is considered a public health priority [3]. Two human models demonstrate the feasibility of developing a malaria vaccine. Immunization with radiation-attenuated Plasmodium spp. parasites has been shown to confer sterile protection against sporozoite challenge in humans [4,5] as well as rodent [6] and nonhuman primate [7] models, and natural long-term exposure to the parasite is associated with an age-related decrease in the incidence, prevalence, and density of infection [8]. The critical effector mechanism in the radiationattenuated sporozoite model is thought to be CD8+ T-cell responses directed against parasite antigens expressed in the liver stage [9-11]. In the naturally acquired immunity model, antibodies directed against blood-stage parasite antigens are thought to be responsible for protective immunity [12-14].

Based on these two models, a multi-stage multi-immune response vaccine against malaria comprising antigens expressed in the liver stage and targeted by T-cell responses, as well as antigens expressed in the blood-stage and targeted by antibody responses, is being developed [15]. The hypothesis is that by reducing the numbers of parasites emerging from the liver ( $T$-cell immune responses directed against those antigens expressed by irradiated sporozoites in hepatocytes) and priming the immune system to erythrocytic stage antigens that will be boosted by infection from natural exposure (antibody responses directed against parasite proteins expressed on the surface of merozoites or infected erythrocytes or in apical organelles), one will reduce the severity and mortality due to Plasmodium falciparum malaria. This "combined stage" approach is designed to prevent infection by killing the majority of developing parasites in the liver, and also to prevent severe disease and death should breakthrough blood stage infections occur. This vaccine development strategy originally called for constructing vaccines consisting of plasmid cocktails of increasing valency, beginning with five pre-erythrocytic stage antigens, and then adding ten or more erythrocytic stage antigens [15]. However, a clinical trial of five pre-erythrocytic stage vaccines (PfCSP, PfSSP2/TRAP, PfLSA1, PfLSA3, PfExp1) indicated reduced immunogenicity to components of a plasmid cocktail in comparison to immune responses to vaccination with individual components [16]. In that trial, none of 31 volunteers immunized with the pentavalent pre-erythrocytic stage vaccine developed T-cell responses to more than three of the five antigens, as measured by IFN- $\gamma$ ELIspot assay and none of the volunteers were protected against $P f$ sporozoite challenge [16]. A lack of protection was also noted in a study combining the $P f C S P$ recombinant protein vaccine RTS, $S$ vaccine and recombinant PfSSP2/TRAP [17]. Interference studies subsequently conducted in mice with mammalian codonoptimized versions of the same five pre-erythrocytic genes plus four erythrocytic stage genes (PfAMA1, PfMSP1-3D7, PfMSP1-FVO, and PfEBA175) showed significant inhibition of antigen-specific T-cell and antibody responses when nine plasmid DNA vaccines were administered as a single cocktail [18]. In vitro expression studies indicated that the inhibition was occurring at the level of mRNA [19]. In a series of plasmid competition experiments, the nine codon-optimized $P$. falciparum plasmid DNA vaccines were assessed for immunogenicity and multi-antigen compatibility, by being tested individually as the nine-valent cocktail, and as a series of eight-valent cocktails in which each single antigen was removed from the cocktail in turn to see if the remaining plasmids were released from an interference effect [18]. Those data led to the down-selection of a five antigen combination of three pre-erythrocytic stage vaccines encoding the $P$. falciparum (3D7 strain) of CSP $[20,21]$, SSP2/TRAP $[22,23]$ and LSA1 $[24,25]$ as well as two erythrocytic stage antigens, AMA1 $[26,27]$, and MSP1-42 $[28,29]$ in which plasmid interference appears to be minimized. This antigen combination has been called CSLAM.

In contrast to recombinant protein approaches, molecular vaccines such as plasmid DNA and recombinant attenuated live viruses rely on the mammalian host's cellular machinery to translate the injected genetic material to 
produce the foreign protein(s) that is expressed in the correct conformation for recognition by the host immune system [30]. Thus, molecular vaccines offer the potential for the construction of multi-antigen immunogens and for activating all arms of the immune system (both antibody and cellular) to confer broad protection against pathogen challenge. The initial emphasis was on plasmid DNA vaccines as a core technology, because of their simplicity of design, ease of modification, combination (potential for multi-antigen vaccination), and manufacturing, and potential for generating the CD8+ T-cell responses required for protection against an intracellular pathogen such as Plasmodium [31,32]. In the malaria model, previous studies have established the capacity of DNA vaccines encoding Plasmodium antigens to induce CD8 ${ }^{+}$CTL and IFN- $\gamma$ responses and protection against sporozoite challenge in mice [15,33-36] and monkeys [37-39]. Phase I/2a clinical trials have established the safety, tolerability and immunogenicity of DNA vaccines encoding malaria parasite antigens in normal healthy humans [3,16,40-44]. However, in multiple disease systems including malaria, DNA vaccines on their own, administered in PBS/saline, have been poorly efficacious with regard to induction of antibody responses and protective immunity in non-human primates [38,39] or humans [16,40-44]. This has led to strategies to enhance the immunogenicity of plasmid DNA, by codon optimization, vaccine/adjuvant formulations, delivery technologies and heterologous DNA prime/virus boost immunization regimens [32,45-49]. One potential DNA immune enhancement strategy is formulation of the DNA with poloxamers - surface active, water-soluble, nonionic triblock copolymers. CRL1005 is a nonionic triblock copolymer composed of blocks of polyoxypropylene (POP) and polyoxyethylene (POE) [50-52] with a POP core of molecular weight $12 \mathrm{kDa}$ and 5\% POE. When formulated with a protein in a vaccine formulation $[51,53]$, these poloxamers have been shown to have adjuvant activity. In addition to enhancing protein or inactivated vaccine-induced antibody responses in rodent models of influenza, CRL1005-formulated plasmid DNA vaccines have been shown to significantly enhance the level of antigen-specific immune responses in SIV non-human primate models after adenovirus boosting [49,50,53]. It is believed that the adjuvant properties of CRL1005 are related to its ability to aggregate into surface-activated particle but the immunological mechanism is unclear. Experimental data suggest that CRL1005-mediated immune enhancement may occur via induction of antibody and IL2 dominated Th- 1 cellular responses, as evidenced in a murine influenza model [54], or induction of IFN- $\gamma$ CD8+ $\mathrm{T}$ cells as evidenced in a SIV non-human primate model [53].
Studies in animal models of various infectious diseases including HIV [55], influenza [56], tuberculosis [57], as well as malaria [47], have established that heterologous prime/boost strategies comprising, for example, priming with plasmid DNA and boosting with recombinant virus, are far more effective than homologous immunization regimens. In particular, priming with plasmid DNA and boosting with recombinant pox was shown to be immunogenic and protective in the Plasmodium yoelii rodent model [34] as well as the Plasmodium knowlesi non-human primate model [39]. Accordingly, using a DNA prime/ poxvirus boost immunization regimen to maximize the potential for enhancing the immunogenicity and protective efficacy of DNA-based vaccines, the ability of the pentavalent CSLAM vaccine cocktail to induce antigenspecific T-cell and antibody responses was evaluated in rhesus monkeys, in comparison with PfCSP alone, both in the absence or presence of the poloxamer CRL1005 aiming to enhance the immunogenicity of plasmid DNA.

\section{Materials and methods Plasmid DNA vaccines}

The plasmid DNA (pDNA) vaccines used in this study, in the VR1020 backbone [58], have been described previously [18]. The PfCSP (VCL-2571), PfSSP2/TRAP (VCL2576), and PfAMA1 (VCL-2577) vaccines encoded fulllength proteins; the PfLSA1 vaccine (VCL-2559) encoded the C-terminal 281 amino acid residues (representing $65 \%$ of the nonrepeat region of full length PfLSA1); and the PfMSP1 vaccine (VCL-2574) encoded the 42-kDa fragment of the PfMSP1 protein. All vaccines were based on the 3D7 strain of $P$. falciparum, and the coding sequence for each antigen was modified for mammalian codon usage in order to improve expression of the encoded antigen [59]. Expression of the encoded protein was confirmed in vitro by transient transfection of VM92 melanoma cells (kindly provided by Vical Inc.) using Lipofectamine, as described by the manufacturer (Life Technologies, Gaithersburg, MD). Protein expression was quantitated as a chemiluminescent signal by using antigen-specific monoclonal or polyclonal antibodies and a commercially obtained chemiluminescence-linked Western blot kit (Western-Light, Tropix, Bedford, Mass.) according to the manufacturer's directions. Chemiluminescent signals were detected by exposure of the processed membrane to auto radiographic film (Hyperfilm-ECL; Amersham Life Sciences Inc., Cleveland, Ohio). Plasmid DNA for immunization was produced by Vical Inc., checked for physical integrity, expression activity, concentration, and endotoxin levels, and resuspended in phosphate-buffered saline (PBS) at a concentration of $2.5 \mathrm{mg}$ of $\mathrm{pDNA} / \mathrm{ml}$ (500 $\mu \mathrm{g}$ of each plasmid DNA vaccine). In the PfCSP alone group, $2 \mathrm{mg}$ of plasmid VR1020 without antigen insert was added to $500 \mu \mathrm{g}$ PfCSP DNA to maintain the total DNA concentration at $2.5 \mathrm{mg} / \mathrm{ml}$. 


\section{CRLI005 formulation}

The poloxamer-based vaccine formulation consisted of the non-ionic block copolymer, CRL1005 (CytRx Corporation, Los Angeles, CA) and a cationic surfactant, benzalkonium chloride (BAK, BTC 50 NF, Stepan Company, Northfield, IL), formulated with pDNA in PBS. To make the formulation, the required concentration of pDNA (to produce a final concentration of $5 \mathrm{mg} / \mathrm{ml}$ ) in PBS was stirred on ice and the required amount of CRL1005 (to produce a final concentration of $7.5 \mathrm{mg} / \mathrm{ml}$ ) was added using a positive displacement pipette. The solution was stirred on ice until the poloxamer dissolved and then the required concentration of benzalkonium chloride dissolved in PBS was added (to produce a final concentration of $0.3 \mathrm{mM}$ ). The solution was then cycled through the cloud point ( 4 to $25^{\circ} \mathrm{C}$ ) several times to ensure homogeneity, diluted with PBS to a final pDNA concentration of $2.5 \mathrm{mg} / \mathrm{ml}$, and then filter sterilized at $4^{\circ} \mathrm{C}$ and stored frozen $\left(-30^{\circ} \mathrm{C}\right)$. Prior to injection, the vaccine formulation was thawed at ambient temperature, stored at room temperature, and administered within 6 hours of preparation.

\section{Recombinant Poxvirus}

ALVAC-Pf7 (virus \# vCP1305, stock \# N37) is a highly attenuated canary poxvirus with seven $P$. falciparum genes (native codon sequence) inserted into its genome: PfCSP and PfSSP2/TRAP (sporozoite stage); PfLSA1 (liver stage); PfAMA1, PfMSP1, and PfSERA (blood stage), and Pfs 25 (sexual stage). The recombinant virus was produced by Virogenetics Corporation (Troy, NY).

\section{Recombinant proteins}

Recombinant PfCSP [60], PfLSA1 (D. Lanar, WRAIR), PfAMA1 [61], and PfMSP1-42 (A. Saul, MVDB) were well characterized $P f$ antigens (3D7 strain) manufactured at research grade. The recombinant proteins were used at a final concentration of $10 \mu \mathrm{g} / \mathrm{ml}$ as antigen for in vitro ELIspot and intracellular cytokine staining assays, and at a final concentration of $1 \mu \mathrm{g} / \mathrm{ml}$ as capture antigen for antibody ELISAs. The endotoxin levels were $<5 \mathrm{EU} / \mathrm{ml}$ for recombinant PfAMA1, and PfMSP1; $13 \mathrm{EU} / \mathrm{ml}$ for PfCSP; and $74 \mathrm{EU} / \mathrm{ml}$ for PfLSA1, as indicated by the LAL testing (Cambrex BioScience Walkersville, Inc, MD).

\section{Synthetic peptides and peptide pools}

A series of 15-mer synthetic peptides, with 10-mer overlaps, derived from PfCSP (total 64 peptides), PfSSP2/ TRAP (total 138 peptides) and PfLSA1 (total 114 peptides) were synthesized by Mimotopes (Melbourne, Australia) at $>80 \%$ purity. Individual peptides were resuspended in DMSO at a concentration of $20 \mathrm{mg} / \mathrm{ml}$ and pooled sequentially according to antigen sequence, with 22 peptides or less per pool. Peptides were used at a final concentration of $4 \mu \mathrm{g} / \mathrm{ml}$ for in vitro T cell assays. The final DMSO concentration did not exceed $0.55 \%$.

\section{Immunization regimen}

A total of 20 rhesus monkeys (Macaca mulatta), aged 5 to 10 years and between 3 and $10 \mathrm{~kg}$ in weight were screened for anti-PfCSP antibody negativity by ELISA and randomized into four groups with five monkeys per group. At weeks 0,4 , and 8, monkeys were immunized with $500 \mu \mathrm{g}$ PfCSP plasmid DNA either in PBS (monkey RZc7, RHc7, RLw6, RSf7, Rli6) or CRL-1005 (monkey RLf7, RUm6, ROr6, RAs6, RDr6), or $500 \mu \mathrm{g}$ of each CSLAM plasmid DNA either in PBS (monkey RDc7, RCf7, RWa7, RYi6, RVi6) or formulated in CRL1005 (PH1019, ROk6, ROa7, RQk6, RBsG) in a total volume of $1 \mathrm{ml}$, administered intramuscularly in single sites in the rectus femoris muscle using a 22-gauge needle. Subsequent immunizations were administered to the same muscle on alternating sides of the animal. Twelve weeks after the last pDNA immunization, animals were boosted by intramuscular administration of $2 \times 10^{8} \mathrm{pfu}$ of ALVAC-Pf7. All immunizations were carried out at the Emory Vaccine Center at the Yerkes National Primate Research Center, Emory University, GA. All experiments were conducted in compliance with the Animal Welfare Act and with Emory University Institutional Animal Care and Use Committee approvals in accordance with the principles set forth in the "Guide for the Care and Use of Laboratory Animals", Institute of Laboratory Animal Resources, National Research Council, and National Academy Press, 1996. Sera and peripheral blood mononuclear cells were collected pre-immunization and at 4 weeks post each immunization for assessment of immunogenicity. The animals were monitored and evaluated daily for general behaviour, level of activity, and visible side effects or adverse reactions. The injection sites were examined closely by the veterinary clinician each time the animals were sedated for designated bleedings and injections. Close observations included analysis of skin for warmth, erythema and edema/swelling, and muscle induration. The clinical veterinarian examining the animals and injection sites was blinded to which vaccine formulation had been given. Analysis of hematology and clinical chemistry of the different animals was performed on blood samples drawn at pre-bleed, immunization and boosting time points. Hematology analysis consisted of an evaluation of white blood cells, erythrocytes, hemoglobin, hematocrit, mean corpuscular volume and platelets values. Analysis of clinical chemistry consisted of glucose, blood urea nitrogen, creatinine, protein, albumin, alkaline phosphatase, serum glutamic pyruvic transaminase, serum glutamic oxaloacetic transaminase, amylase and creatine phosphokinase determinations.

\section{IFN- $\gamma$ ELIspot assay}

The assay for rhesus IFN- $\gamma$ was modified from a previously described method [62]. In brief, 96-well PVDF plates (Millipore Corporation, Bedford, MA) were coated with 100 $\mu \mathrm{l} /$ well of anti-human IFN- $\gamma$ mAb (clone GZ-4, Bend- 
erMedSystems, Burlingame, CA) at a concentration of 5 $\mu \mathrm{g} / \mathrm{ml}$ in $1 \times$ PBS and incubated overnight at $4^{\circ} \mathrm{C}$. Plates were washed six times with RPMI 1640 medium and blocked with $200 \mu \mathrm{l} /$ well of $10 \%$ FCS-RPMI 1640 medium (R10) for at least $2 \mathrm{hr}$ at $37^{\circ} \mathrm{C}$. After blocking, the plates were washed once with R10, and $100 \mu \mathrm{l}$ of $2 \times 10^{6}$ PBMC (200,000 cells/well) and $100 \mu$ l of stimulant in R10 were added per well, in quadruplicate. Plates were incubated for $18 \mathrm{hrs}$ at $37^{\circ} \mathrm{C}$ in an atmosphere of $5 \%$ $\mathrm{CO}_{2}$. Plates were then washed six times with $1 \times \mathrm{PBS}$ in the presence of $0.5 \%$ Tween 20 (PBS-T) $100 \mu \mathrm{l} /$ well of $1 \mu \mathrm{g} /$ ml biotinylated anti-IFN- $\gamma$ (clone 7-B6-1, MabTech, Sweden) added per well, and the plates incubated for $1 \mathrm{hr}$ at $37^{\circ} \mathrm{C}$. Plates were washed six times with $1 \times$ PBS-T, and $100 \mu \mathrm{l} /$ well streptavidin-alkaline phosphatase conjugate (MabTech, Sweden) was added at 1:1000 dilutions in PBS. After $1 \mathrm{hr}$ incubation at room temperature, plates were washed six times with $1 \times$ PBS-T followed by three times with PBS, and developed with AP conjugate substrate kit, (BioRad Laboratories, Hercules, CA) according to the manufacturer's instructions. After $15 \mathrm{~min}$, the plates were rinsed extensively with $\mathrm{dH}_{2} \mathrm{O}$ to stop the colorimetric reaction, dried and stored in the dark. The IFN- $\gamma$ spotforming cells (SFC) were numerated using a high-resolution automated ELIspot reader (Carl Zeiss Vision, Germany). Responses were expressed as the mean number of SFC per million cells in quadruplicate wells. Responses, to both protein and peptide pools, were classified as positive if (1) the net SFC (mean SFC in experiment antigen wells - mean SFC in medium wells) was > 25 SFC per million PBMC, and (2) the stimulation index (ratio of mean SFC in experimental peptide wells to mean SFC in medium wells) was $>2$. In some cases, responses in cells collected before immunization to a specific immunogen met the criteria of positivity as defined above. In that case, responders post immunization were classified as positive if the magnitude of net ELIspot was > 2-fold that of the pre-immunization response.

\section{Intracellular cytokine staining}

All reagents for the intracellular cytokine staining were purchased from Becton Dickinson ImmunoCytometry Systems (San Jose, CA). A total of $0.5-1.0 \times 10^{6}$ PBMC in $100 \mu \mathrm{l}$ R10 medium were plated per well in U-bottomed 96-well plates, in the presence of $1 \mu \mathrm{g} / \mathrm{ml}$ anti-human CD28 (Clone CD28.2) and $1 \mu \mathrm{g} / \mathrm{ml}$ anti-human CD49d (clone 9F10) antibodies with or without $100 \mu$ antigen (total $200 \mu \mathrm{l} /$ well). GolgiPlug was added at $1 \mu \mathrm{l} /$ well at 2 hrs after the start of incubation, and the plates were then incubated an additional $14 \mathrm{hrs}$ at $37^{\circ} \mathrm{C}$ in an atmosphere of $5 \% \mathrm{CO}_{2}$. Plates were spun at $1,200 \mathrm{rpm}$ for $5 \mathrm{~min}$, the supernatant flicked, the cell pellet resuspended by gentle vortexing, and the cells washed twice in FACS buffer. The cells were stained with $20 \mu \mathrm{l}$ anti-CD4-PerCP-Cy5.5 (clone L200), and $5 \mu$ l anti-CD8-PE-Cy7 (clone RPA-T8) in a final volume of $100 \mu$ l FACS buffer for 45 min on ice in the dark. After the surface staining, cells were washed with FACS buffer twice, gently resuspended, and permeabilized in $100 \mu \mathrm{l}$ CytoFix/CytoPerm buffer for $20 \mathrm{~min}$. Cells were washed again and then stained with anti-IFN- $\gamma$ FITC (clone B27) and anti-IL2-APC (clone MQ1-17H12) for $45 \mathrm{~min}$ on ice in the dark. Cells were washed twice with CytoPerm wash buffer, resuspended in $200 \mu$ of FACS buffer, and stored at $4{ }^{\circ} \mathrm{C}$ prior to analysis. Samples were analysed using the FACSCalibur ${ }^{\mathrm{TM}}$ flow cytometer (Becton Dickinson Immunocytometry Systems, San Jose, CA) and CellQuest software. The expression level of intracellular cytokines was presented as the percentage of stained cells in gated cell populations of either CD4+ or CD8+ cells, corrected for background responses in the absence of antigen. The non-specific background was typically less than $0.05 \%$.

\section{Antibody assays}

Pre- and post-immunization serum samples were serially diluted two-fold and assayed in parallel for anti-Plasmodium antibodies. Parasite-specific antibodies were assayed by the indirect fluorescent-antibody test (IFAT) [63] against air-dried P. falciparum (strain NF54 3D7 clone) sporozoites or parasitized erythrocytes. IFAT results were reported as the endpoint dilution, representing the last serum dilution at which fluorescence was scored as positive. Antigen-specific antibodies were assayed by the enzyme-linked immunosorbent assay (ELISA) [63,64] against recombinant PfCSP $(0.5 \mu \mathrm{g} / \mathrm{ml})$, PfSSP2/TRAP $(1.0 \mu \mathrm{g} / \mathrm{ml}), \operatorname{PfLSA} 1(1 \mu \mathrm{g} / \mathrm{ml}), \operatorname{PfAMA} 1(1 \mu \mathrm{g} / \mathrm{ml})$, or PfMSP1 $(1 \mu \mathrm{g} / \mathrm{ml})$ proteins. ELISA results were reported as OD 0.5 units, representing the reciprocal of the serum dilution at which the mean OD reading was 0.5. ELISA responses were classified as positive if (1) titer of OD 0.5 units was > 25 and (2) the seroconversion index (ratio of titer post-immunization to titer pre-immunization) was $>$ 4.

\section{Statistical analysis}

Experimental outcomes were presented as direct results of ELIspot assays (IFN- $\gamma$ spot forming cells/million splenocytes), FACS analysis (\% responding cells), ELISA (antibody titers) or IFAT (antibody titers). Comparison of ELISA data and intracellular cytokine expression were done by 2-tailed student $t$ test. ELIspot data are reported as mean +/- standard deviation of quadruplicate wells. Responses to all individual antigens, either recombinant proteins (PfCSP, PfLSA1, PfAMA1, and PfMSP1) or peptide pools (i.e. three PfCSP pools, seven PfSSP2/TRAPpools, six PfLSA1 pools), were analysed with an analysis of variance for a repeated measures design with one between-subjects factor (vaccine group at four levels), and one within-subjects factor (time at six levels). All pair-wise comparisons of means were made with Fisher's LSD (Least 
Significant Difference) test. The sums of the peptide pools were analysed with the same methods. The recombinant proteins were analysed with the same methods except for the addition of one between-subjects factor (called r-protein with 4 and 5 levels, respectively, for analyses with and without PfSSP2/TRAP). Fisher's exact test was used informally to conduct pair-wise vaccine group comparisons of positive responder rates. Trends over time were examined with graphs, but no formal statistical tests of significance were conducted to test for significant trend components (i.e. linear, quadratic or cubic components). The p-value considered significant was $\mathrm{p}<0.05$.

\section{Results}

\section{Clinical evaluation}

Animals were evaluated daily for general behaviour and the presence of any adverse reactions or clinical abnormalities, as described in Material and Methods. No unusual behaviour or adverse reactions were observed throughout the course of the trial. Haematology and clinical chemistry values remained within the normal range.

\section{Antigen-specific and parasite-specific antibody responses} The induction of parasite-specific and antigen-specific antibody responses post vaccination was assessed by IFAT against air-dried $P f$ sporozoites or parasitized erythrocytes, and by ELISA against each vaccine antigen component, respectively. IFAT responses were evaluated pre- immunization, after the $3^{\text {rd }}$ DNA immunization, and after virus boost. Positive IFAT responses against $P f$ sporozoites were detected post DNA immunization in 5/5 animals in the CSLAM/PBS immunized group but $0 / 5$ in the PfCSP/ PBS immunized group (data not presented). The titer of IFAT increased approximately five-fold after virus boost (mean, 160 versus 30 ). No blood-stage parasite specific antibodies were detected by IFAT at any time point.

To determine whether co-immunization of PfCSP with four additional antigens, PfSSP2/TRAP, PfLSA1, PfAMA1 and PfMSP1 in PBS (i.e. the other antigens of the CSLAM/ PBS cocktail), adversely affected the PfCSP-antigen specific antibody responses, the frequency of positive responders and the magnitude of ELISA responses were compared between PfCSP/PBS immunized and CSLAM/ PBS immunized animals. No antigen-specific antibodies were detected after the first DNA immunization. In monkeys immunized with $P f C S P / P B S$ alone, anti-PfCSP antibodies could not be detected until after third DNA immunization, when only1/5 monkeys met the criteria of positivity and remained positive after virus boost (Figure 1). In monkeys immunized with CSLAM/PBS, however, anti-PfCSP antibodies were detected in $1 / 5$ monkeys after the $2^{\text {nd }}$ immunization, $3 / 5$ monkeys after $3^{\text {rd }}$ DNA immunization, and 5/5 monkeys after virus boost. The antiPfCSP antibody response was significantly higher in the CSLAM/PBS immunized responder monkeys as compared

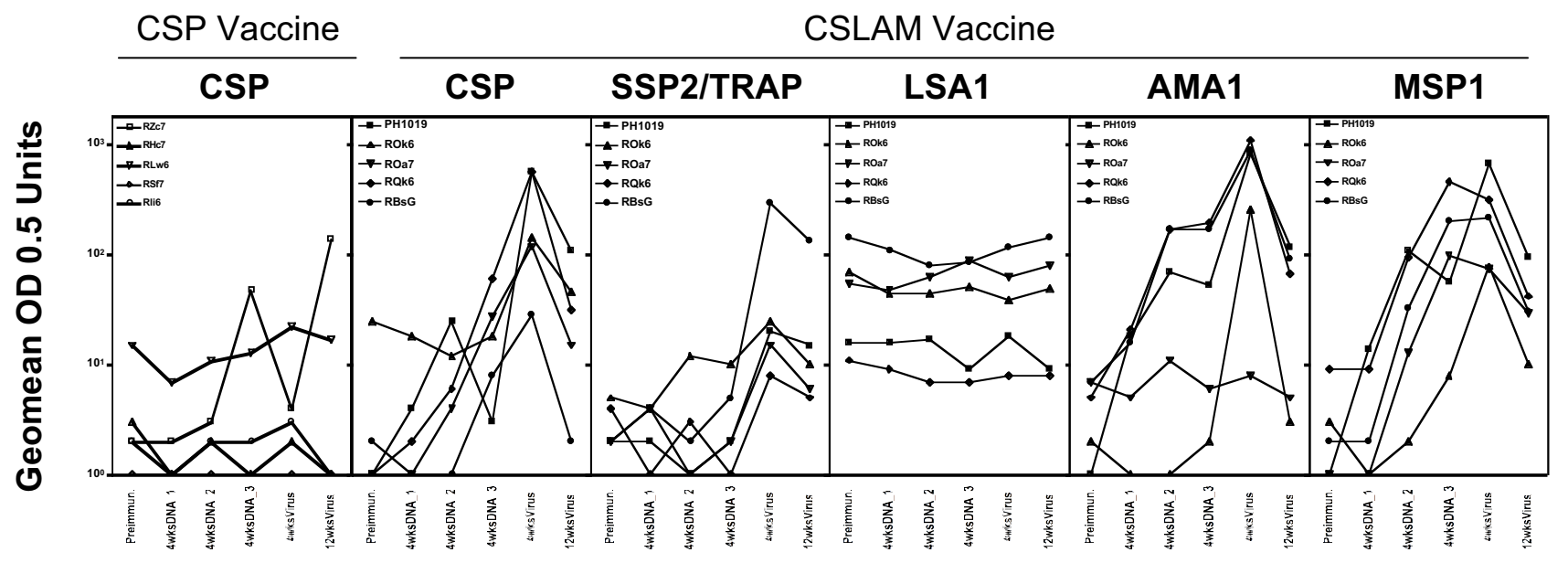

Figure I

Antigen-specific antibody responses against pre-erythrocytic antigens PfCSP, PfSSP2/TRAP, PfLSA I and blood stage antigens PfAMAI and PfMSPI. Sera from monkeys immunized with either CSP/PBS or CSLAM/PBS were assayed against PfCSP, PfSSP2/TRAP, PfLSAI, PfAMAI or PfMSPI capture antigens by ELISA. Data are presented as the geometric means of titers at OD 0.5 units from individual monkeys per group. ELISA responses were classified as positive if (I) OD0.5 unit titer was > 10; and (2) the seroconversion index (ratio of titer post-immunization to titer pre-immunization) was $>4$. Preimmun = preimmunization; 4wksDNA_I $=4$ wks post Ist DNA immunization; 4wksDNA_2 $=4$ wks post $2^{\text {nd }}$ DNA immunization; 4wksDNA_3 = 4 wks post 3rd DNA immunization; 4wksVirus = 4 wks post ALVAC-Pf7 boost; 12 wksVirus = I 2 wks post ALVAC-Pf7 boost. 
with $P f C S P / P B S$ immunized responders after the viral boost ( $\mathrm{p}=0.044)$, but not after DNA immunization ( $\mathrm{p}=$ $0.20)$. In the CSLAM/PBS group, anti-PfAMA1 and antiPfMSP1 antibodies were detected in 0/5 monkeys after the $1^{\text {st }}$ DNA immunization, $3 / 5$ monkeys after $2^{\text {nd }}$ DNA immunization, 3/5(PfAMA1) or 4/5 (PfMSP1) after the $3^{\text {rd }}$ DNA immunization, and 4/5 (PfAMA1) or 5/5 (PfMSP1) monkeys after the viral boost. Anti-PfSSP2/ TRAP antibodies were detected in 2/5 monkeys post-viral boost only. No anti-PfLSA1 specific antibody responses were detected at any time point. After virus boosting, antibody titers increased approximately 6-fold for PfCSP, 9fold for PfAMA1, and 2-fold for PfMSP1 (Figure 1). Overall, the most immunogenic antigen with regard to antibody response was PfAMA1.

\section{PfCSP-specific ELIspot responses}

Overall, antigen-specific IFN- $\gamma$ ELIspot responses were observed in 18/20 immunized monkeys regardless of groups and immunogens, and responses were detected as early as 4 weeks after a single DNA immunization. The two non-responder monkeys were monkey RCf7 (CSLAM/CRL10005) and monkey RHc7 (CSP/PBS). The average SFC from positive responders post $1^{\text {st }} \mathrm{DNA}$ immunization (mean 102 SFC/million, range 0-273 SFC/million) was approximately 5 times higher than the average SFC response before immunization (20 SFC/million, $\mathrm{p}<$ $0.05)$ (Figure 2). The ELIspot responses plateaued post $2^{\text {nd }}$ (mean 95, range 0-286 SFC/million) and $3^{\text {rd }}$ (mean 83, range 0-401 SFC/million) DNA immunizations but were boosted by ALVAC-Pf7 with magnitudes increasing to an average of $152 \mathrm{SFC} /$ million (range 0-466 SFC/million, p $=0.005$ compared to preimmunization) at 4 weeks post virus boost. The response then declined at 12 weeks post viral boost to a level similar to that prior to the boost (mean 79, range 0-268 SFC/million). A similar pattern of PfCSP-specific IFN- $\gamma$ ELIspot responses was observed to synthetic PfCSP peptide pools, although the overall magnitude of SFC to individual peptide pools was not as great as to the recombinant protein (data not presented). These data confirm previous studies by us [37], demonstrating the immunogenicity of PfCSP plasmid DNA in rhesus monkeys via detection of CTL activity at 3 weeks after the $2^{\text {nd }}$ DNA immunization. In that study, the PfCSP DNA was native rather than mammalian codon optimized, and CTL responses could not be detected after a single DNA immunization. In other studies in the $P$. knowlesi/rhesus model, with native $P$. knowlesi antigens, no response could be detected even after three DNA immunizations $[38,39]$.

\section{Comparison of PfCSP-specific IFN- $\gamma$ ELIspot responses between PfCSP and CSLAM groups}

To determine whether co-immunization of PfCSP with PfSSP2/TRAP, PfLSA1, PfAMA1, and PfMSP1 adversely affected the PfCSP-antigen specific T cell responses, the

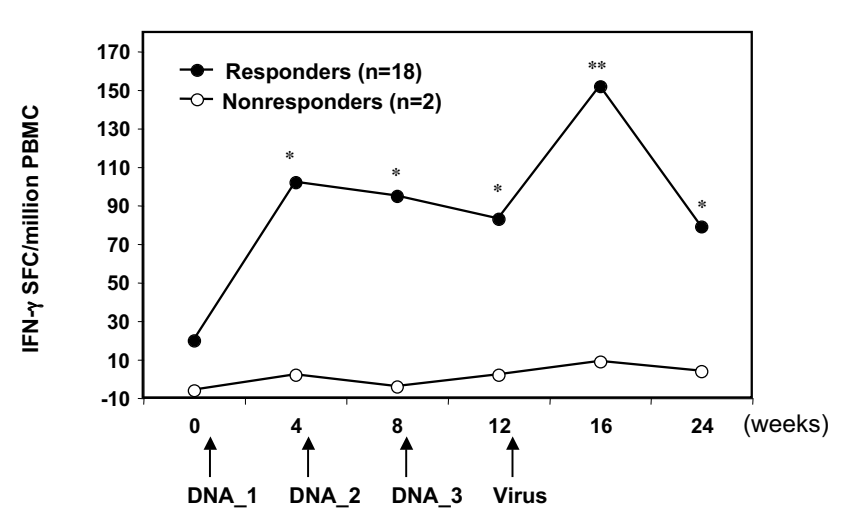

Figure 2

Antigen-specific IFN- $\gamma$ responses against pre-erythrocytic antigen PfCSP. PBMC from PfCSP or CSLAM immunized monkeys (both PBS and CRLI005 formulations) were assayed against recombinant PfCSP protein by IFN- $\gamma$ ELIspot. Results represent the mean net spot-forming cells (SFC) per million PBMC from all responders $(n=18)$ (solid circle) or non-responders $(n=2)$ (open circle) at the defined time points. DNA_I = $\left.\right|^{\text {st }}$ DNA immunization; DNA_2 $=2^{\text {nd }}$ DNA immunization; DNA_3 = 3rd DNA immunization; Virus = ALVAC-Pf7 boost. Net SFC was calculated by correcting the SFC responses with antigen for background SFC without antigen. IFN- $\gamma$ ELIspot responses were classified as positive if (I) the net SFC (mean SFC in experiment antigen wells mean SFC in medium wells) was $>25$ SFC per million PBMC, and (2) the stimulation index (ratio of mean SFC in experimental peptide wells to mean SFC in medium wells) was $>2$. $\left(*_{p}<0.05\right.$ and $\left.*^{*} p<0.01\right)$.

frequency of positive responders and the magnitude of ELIspot responses were compared between PfCSP/PBS immunized and CSLAM/PBS immunized animals. There was no significant difference between the frequency of PfCSP-specific IFN- $\gamma$ positive responders in monkeys immunized with PfCSP/PBS alone or with PfCSP in the pentavalent cocktail CSLAM/PBS at anytime point, as determined by responses against both recombinant protein and synthetic peptide immunogens (Table 1). Interestingly, and consistent with the antibody data presented above, there were more PfCSP responders in the group immunized with CSLAM/PBS as compared to the group immunized with PfCSP/PBS alone.

Similarly, there was no significant difference in the magnitude of PfCSP-specific IFN- $\gamma$ ELIspot responses between the PfCSP/PBS and CSLAM/PBS groups (Figure 3). At four weeks post $3^{\text {rd }}$ DNA immunization, the SFC/million in responders to recombinant $P f C S P$ protein ranged between 145 and 401 SFC/million (mean 269 SFC/million PBMC) for the CSLAM/PBS group as compared with a range of 40-102 SFC/million (average $71 \mathrm{SFC} /$ million) for the $P f C S P / P B S$ group. At 4 wks post viral boost, the magni- 
Table I: Frequency of positive responders to PfCSP in CSP and CSLAM groups

\begin{tabular}{|c|c|c|c|c|}
\hline & \multicolumn{2}{|c|}{ Recombinant Protein } & \multicolumn{2}{|c|}{ Synthetic Peptide Pools } \\
\hline & CSP & CSLAM & CSP & CSLAM \\
\hline Preimmunization & $0 / 5$ & $0 / 5$ & $0 / 5$ & $0 / 5$ \\
\hline 4wksDNA_I & $2 / 5$ & $2 / 5$ & $0 / 5$ & $0 / 5$ \\
\hline 4wksDNA_2 & $2 / 5$ & $2 / 5$ & $0 / 5$ & $0 / 5$ \\
\hline 4 wksDNA_3 & $2 / 5$ & $2 / 5$ & $0 / 5$ & $0 / 5$ \\
\hline 4wksVirus & $2 / 5$ & $3 / 5$ & $1 / 5$ & $2 / 5$ \\
\hline I 2wksVirus & $2 / 5$ & $4 / 5$ & $2 / 5$ & $4 / 5$ \\
\hline
\end{tabular}

tude of IFN- $\gamma$ ELIspot forming cells was 246 SFC/million (range 51-466 SFC/million PBMC) for the CSLAM/PBS group versus $284 \mathrm{SFC} /$ million (range 162-406 SFC/million $\mathrm{PBMC}$ ) for the PfCSP/PBS group.

These ELIspot data, together with the antibody data above, demonstrate that co-immunization of PfCSP with two other pre-erythrocytic stage antigens (PfSSP2/TRAP, PfLSA1) and two erythrocytic stage antigens (PfAMA1 and PfMSP1) does not adversely affect the immunogenicity of PfCSP. These data support the down-selection of the CSLAM antigen combination, as determined by studies in the P. yoelii model [18].

\section{CSLAM-specific ELIspot responses}

Antigen-specific responses to the other components of the CSLAM vaccine were also assessed. As shown in Figure 4A, antigen-specific IFN- $\gamma$ ELIspot response to all other components of CSLAM/PBS vaccine (PfLSA1 recombinant

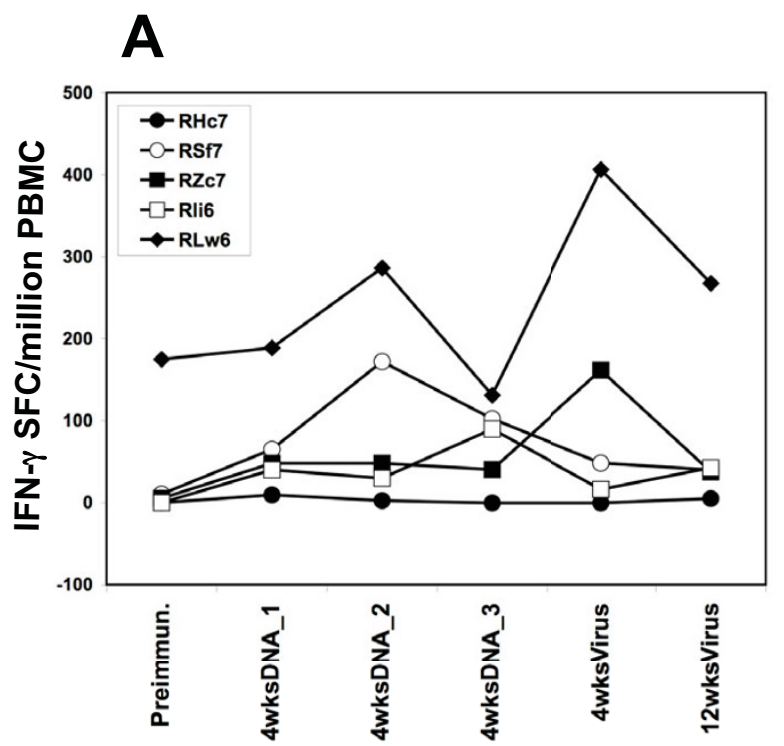

protein and synthetic peptides, PfSSP2/TRAP synthetic peptide, PfAMA1 recombinant protein, and PfMSP1 recombinant protein) were induced by DNA immunization and were boosted by ALVAC-Pf7 (peptide data other than PfSSP2/TRAP not presented). IFN- $\gamma$ responses to PfSSP2/TRAP and PfMSP1 were detected in 5/5 CSLAM/ PBS immunized monkeys, and responses to PfCSP, PfLSA1 and PfAMA1 were detected in 4/5 monkeys. Positive responses to $P f \mathrm{LSA} 1$ and $P f A M A 1$ were observed after the $1^{\text {st }}$ DNA immunization, as noted for PfCSP, whereas positive responders to PfSSP2/TRAP and PfMSP1 were detected only after the $2^{\text {nd }}$ DNA immunization. After the ALVAC-Pf7 boost, at least 3/5 monkeys met the defined criteria of positive responses for each immunogen (Figure $4 \mathrm{~A})$.

The magnitude of vaccine-induced IFN- $\gamma$ ELIspot responses in the 5 CSLAM/PBS immunized monkeys to each of the CSLAM components is shown in Figure 4B.

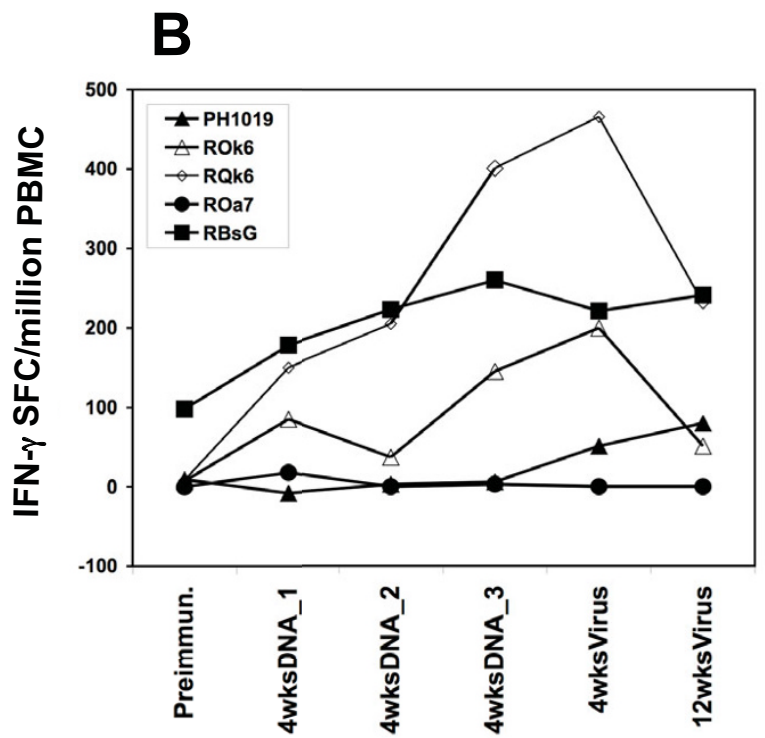

Figure 3

Magnitude of PfCSP-specific IFN- $\gamma$ responses from PfCSP/PBS and CSLAM/PBS immunized animals. PBMC were collected at time points as defined in the legend to Figure 2 and assayed against recombinant PfCSP protein by IFN- $\gamma$ ELIspot. Results show the magnitude of SFC from individual monkeys immunized with either (A) PfCSP/PBS or (B) CSLAM/PBS. 

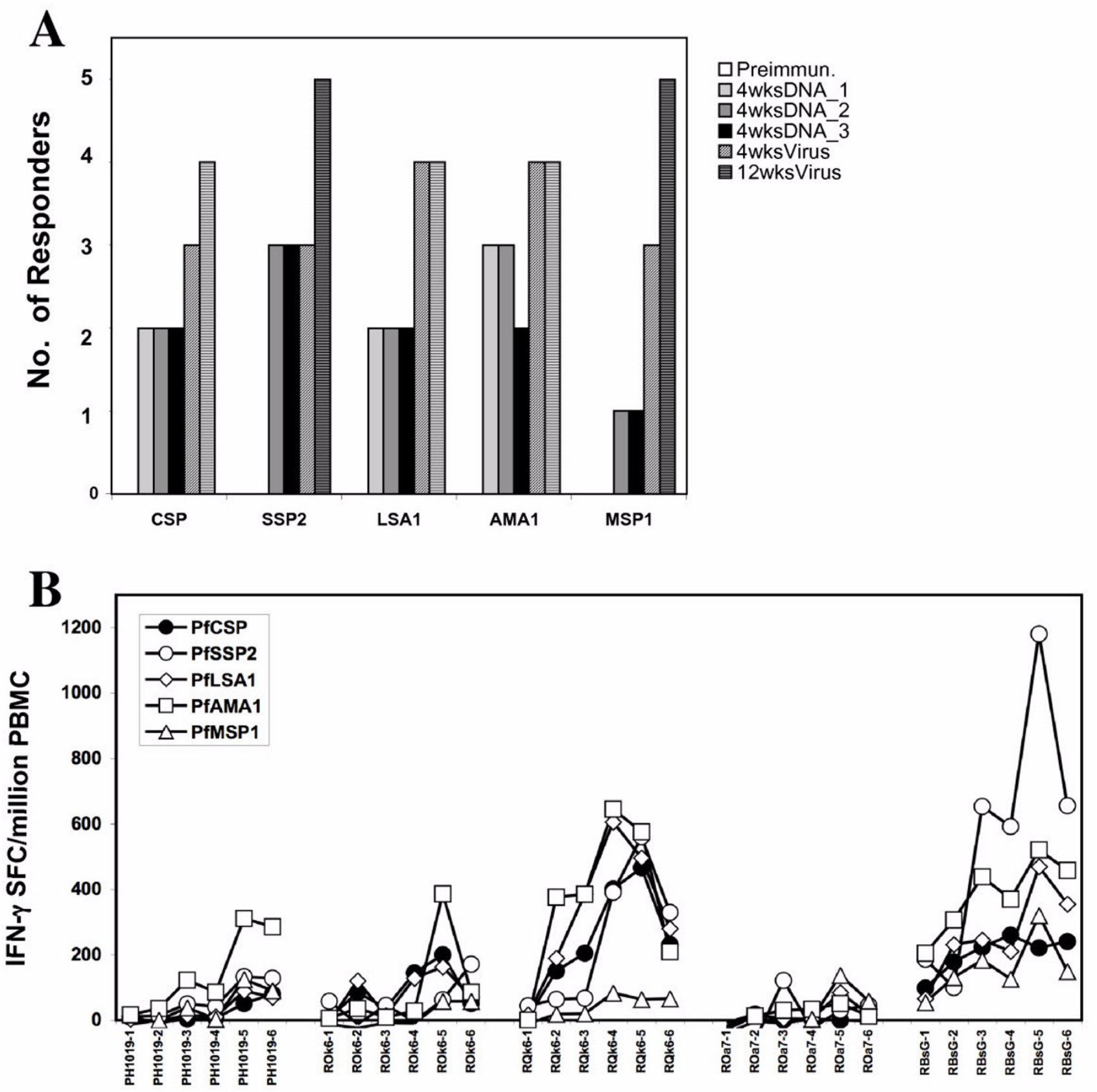

\section{Figure 4}

A. Frequency of IFN- $\gamma$ ELIspot responders to all CSLAM antigen components in CSLAM/PBS immunized monkeys. Monkeys were immunized with CSLAM/PBS, and PBMC collected at time points as defined in the legend to Figure 2 were assayed against recombinant PfCSP, PfLSAI, PfAMAI or PfMSPI protein and PfSSP2/TRAP peptide pools by IFN- $\gamma$ ELIspot. B. Magnitude of IFN- $\gamma$ ELIspot responses to all CSLAM antigen components in CSLAM/PBS immunized monkeys. Monkeys were immunized with CSLAM/PBS and PBMC collected at defined time points were assayed against recombinant PfCSP, PfLSAI, PfAMAI or PfMSPI protein and PfSSP2/TRAP peptide pools by IFN- $\gamma$ ELlspot. Time point number I, 2, 3, 4, 5, and 6 represent time points pre-immunization, 4 wks post Ist DNA immunization, 4 wks post $2^{\text {nd }}$ DNA immunization, 4 wks post $3^{\text {rd }}$ DNA immunization, 4 wks post ALVAC-Pf7 boost, and 12 wks post ALVAC-Pf7 boost, for monkeys PHI0I9, ROk6, RQk6, ROa7 and RBsG, respectively. 


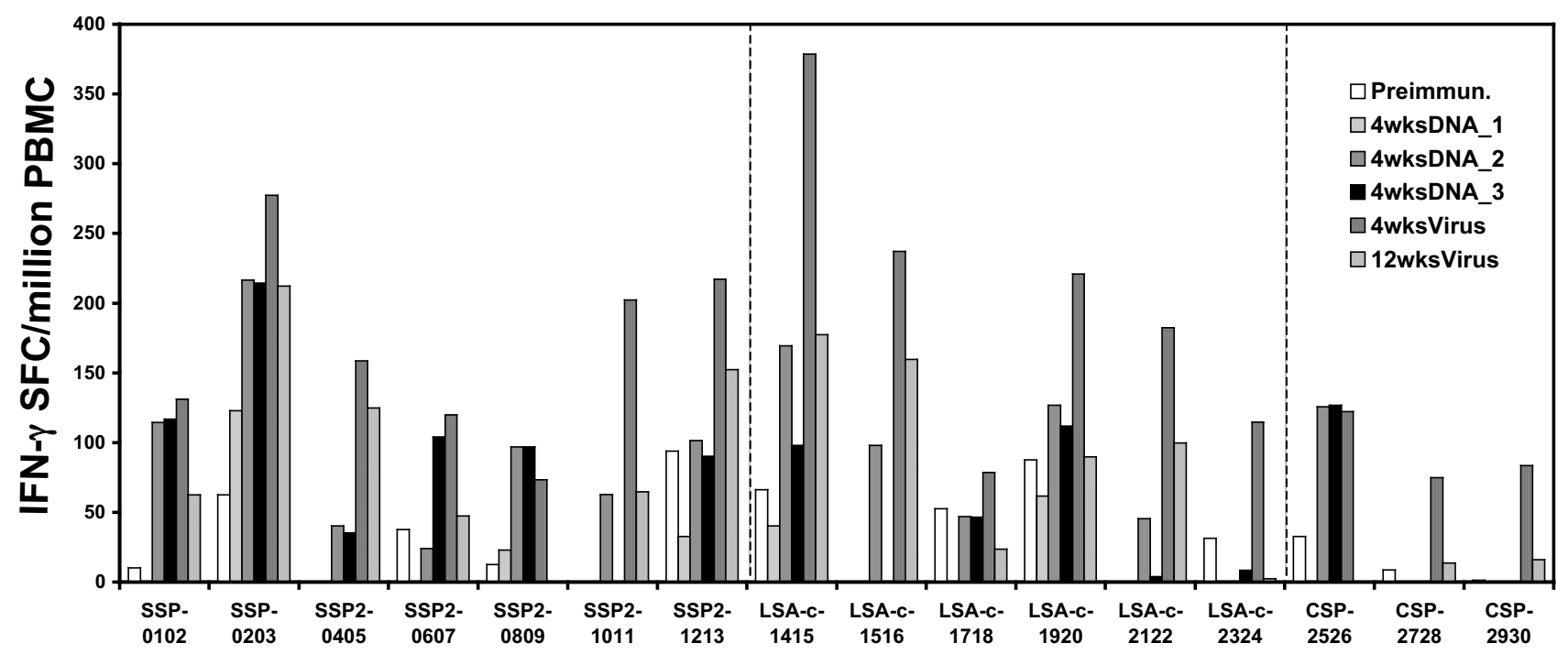

Figure 5

IFN- $\gamma$ responses to individual peptide pools derived from PfCSP, PfSSP2/TRAP or PfLSAI. PBMC from monkey RBsG (CSLAM/PBS) collected at time points as defined in the legend to Figure 2 were assayed against pools of synthetic peptides spanning the complete sequences of PfCSP, PfSSP2/TRAP or PfLSAI by IFN- $\gamma$ ELlspot.

The most robust response, at 4 weeks post virus boost, was against PfAMA1 (in 4/5 monkeys); this response was not significantly different from the anti-PfLSA1 response $(\mathrm{p}>$ $0.05)$ but was significantly higher than the PfCSP- and PfMSP1-specific responses ( $\mathrm{p}<0.05)$. Of the five antigens tested, PfMSP1 was the least immunogenic for T cell responses at all time points. For all antigens and all responder monkeys (with the exception of one PfCSP immunized monkey), IFN- $\gamma$ ELIspot responses were boosted byALVAC-Pf7 virus. All boosted responses decreased within 12 weeks post viral boost to a level similar to that prior to the boost.

Consistent with the known genetic restriction of $\mathrm{T}$ cell responses to Plasmodium proteins [65], heterogeneity of IFN- $\gamma$ responses amongst individual monkeys was noted. The same monkey did not respond to all antigens, and different monkeys responded to different antigens (Figures $4 \mathrm{~A}$ and $4 \mathrm{~B}$ ). For example, at four weeks post virus boost, two monkeys responded to five antigens, one to four antigens, one to two antigens, and one to only one antigen. The most robust IFN- $\gamma$ responses to all five antigens were detected in monkey RBsG in the CSLAM/PBS group; strong responses to recombinant PfCSP, PfAMA1, PfSSP2/ TRAP, and PfLSA1 but not PfMSP1, were detected in monkey RQk6; monkeys PH1019 and ROk6 exhibited strong responses to PfAMA1 but weak response to the other four antigens; and monkey ROa7 had a poor response to PfMSP1 and no response to the other four antigens.
For those antigens for which synthetic peptides spanning the complete antigen were available (PfCSP, PfSSP2/ TRAP, and PfLSA1), responses to multiple peptide epitopes were detected. Representative data for responses in monkey $\mathrm{RBsG}$, the most reactive monkey in the CSLAM/PBS group, are presented in Figure 5. Among the three antigens (and consistent with the recombinant protein reactivity reported above), the most robust IFN- $\gamma$ responses were detected to PfLSA1, with positive responses to five of the six peptide pools. The most N-terminal pool LSA1-1415 (residues 1-84) was the most immunogenic, with an average of 380 SFC/million PBMC at 4 wks post ALVAC-Pf7 boost. The magnitude of IFN- $\gamma$ responses in three of the other four PfLSA1 peptide pools was comparable, and the least reactive pool was LSA1-1718 (residues 132-236). Similarly, for PfCSP, the most immunogenic peptide pool was the most N-terminal pool CSP-2526 (residues 1-184), although the magnitude of responses to PfCSP peptide pools was lower than that for the other two antigens. The frequency and magnitude of responses to the PfSSP2/TRAP peptide pools were variable; the most immunoreactive pool was residues 44-128, with an average of 277 SFC/million PBMC at 4 wks post viral boost.

These data establish that $\mathrm{T}$ cell responses to each component of the CSLAM/PBS vaccine were detected in rhesus monkeys following DNA immunization and were boosted by ALVAC-Pf7. 
A

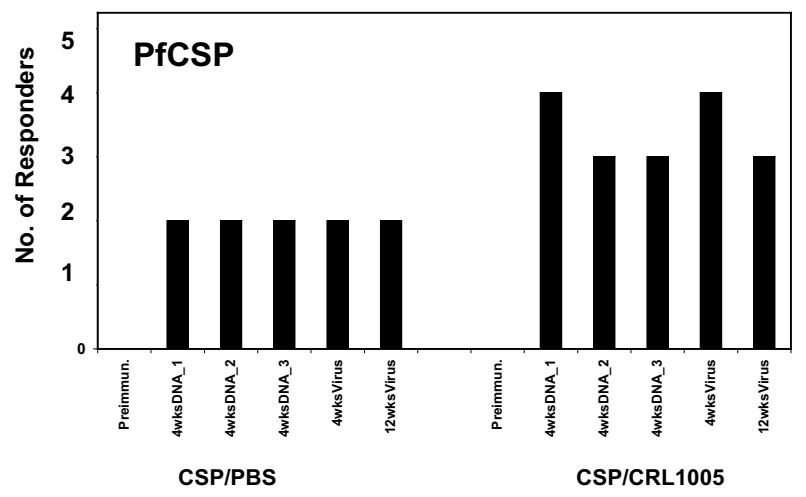

B

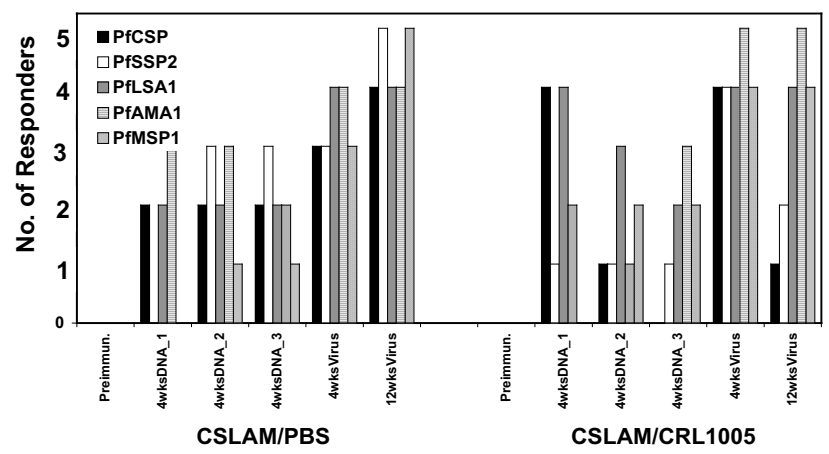

Figure 6

Effect of CRL 1005 formulation on frequencies of IFN$\gamma$ ELlspot responders in (A) PfCSP or (B) CSLAM immunized monkeys. Monkeys were immunized with either PfCSP or CSLAM in PBS (open circle) or formulated in CRLIO05 (solid circle). PBMC were collected at time points as defined in the legend to Figure 2 and assayed against recombinant PfCSP, PfLSAI, PfAMAI or PfMSPI protein and PfSSP2/TRAP peptide pools by IFN- $\gamma$ ELIspot. Data represent the number of animals with responses that met the defined criteria of positivity (SFC $=25$ and $\mathrm{SI}=2$ ).

\section{Effects of CRLIO05 formulation on immunogenicity of PfCSP and CSLAM vaccines}

To investigate the capacity of CEL1000 to enhance the immunogenicity of plasmid DNA, the frequency and magnitude of antigen-specific IFN- $\gamma$ T cell responses, and parasite-specific and antigen-specific antibody responses, in monkeys administered PfCSP or CSLAM formulated in CRL1005, were evaluated in comparison with those in PBS. The frequencies of responders to PfCSP in the PfCSP/ PBS and CSP/CRL1005 immunized monkeys, and the frequencies of responders to each CSLAM antigen in the CSLAM/PBS and CSLAM/CRL1005 group, are presented in Figure 6. The respective magnitudes of responses are presented in Figure 7. Overall, for PfCSP as well as the other CSLAM antigens, there was no measurable effect of CRL1005 formulation on enhancement of either fre- quency (Figures 6A and 6B) or magnitude (Figure 7) of IFN- $\gamma$ responses.

Likewise, there was no apparent effect of CRL1005 formulation on the frequency or magnitude of antibody responses to PfCSP in PfCSP immunized animals, nor to any of the CSLAM antigen components in CSLAM immunized monkeys (Additional File 1).

\section{Intracellular IFN- $\gamma$ and IL-2 expression by CD4+ and CD8+ $T$ cells}

The ELIspot assay as reported here measures the total number of cytokine secreting cells within a bulk cell population and does not allow discrimination between the responding cell phenotype(s). Therefore, to determine the phenotypes of IFN- $\gamma$-producing cells, the intracellular expression of IFN- $\gamma$ and IL-2 for CD4+ and CD8+ T cell subsets, in CSLAM immunized monkeys was measured. Based on cell availability, PBMC from three monkeys (ROa7, RQk6, RBsG), collected at preimmunization and four weeks post virus boost time points, were analysed against peptide pools derived from PfCSP, PfSSP2/TRAP and PfLSA1. Figure 8 shows the result of this analysis from the monkey RBsG, for PfSSP2/TRAP and PfLSA1. Peptide pools PfSSP2/TRAP-1011 (residues 396-495), PfSSP2/ TRAP-1213 (residues 484-562), PfLSA1-1415 (residues 1-84) and PfLSA-1516 (residues 44-143) preferentially induced CD4+ IL-2 responses, with low level CD4+IFN- $\gamma$ responses. All four pools also induced low level CD8+ IFN- $\gamma$ responses, and two of them induced low level CD8+ IL-2 responses (Figure 8 ). These data indicate that the CSLAM DNA vaccines preferentially induce CD4+ T cell cytokine responses, rather than $\mathrm{CD} 8+\mathrm{T}$ cell responses, and that IL-2 responses predominate over IFN- $\gamma$ responses. The data reported above describing the correlation of summed IFN- $\gamma$ responses to synthetic peptide overlaps and IFN- $\gamma$ responses to the recombinant protein also suggested that the IFN- $\gamma$ responses were mediated by CD4+ T cells, rather than CD8+ T cells. Taken together, these data indicate that CD4 T cells, rather than CD8+ T cells, are primarily responsible for the antigen-specific IFN- $\gamma$ responses detected by ELIspot, at least under the conditions evaluated herein.

\section{Discussion}

A multi-stage multi-immune response vaccine is designed to prevent Plasmodium infection by killing the majority of developing parasites in the liver, and also to prevent severe disease and death should break-through blood stage infections occur. Recent efforts are aimed at the induction of robust immune responses directed against five well characterized $P$. falciparum antigens: three preerythrocytic stage proteins that are expressed by irradiated sporozoites in infected hepatocytes (PfCSP, PfSSP2/TRAP, PfLSA1), and two proteins expressed in the extracellular 

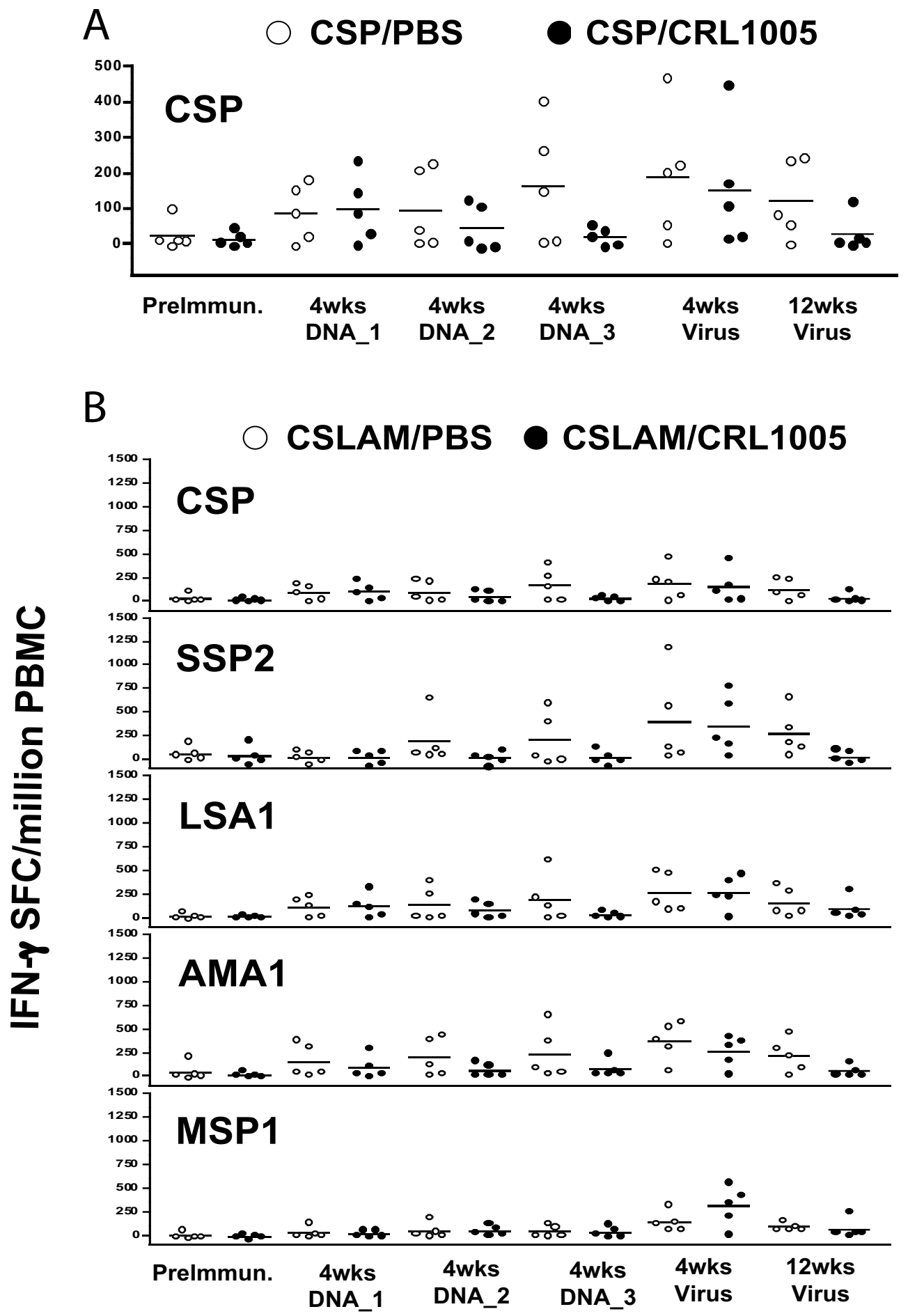

Figure 7

Effects of CRLI 005 formulation on the magnitude of IFN- $\gamma$ ELIspot responses in (A) PfCSP/PBS versus PfCSPI CRLI 005 or (B) CSLAM/PBS versus CSLAM/CRLI 005 immunized monkeys. Monkeys were immunized with either PfCSP or CSLAM in PBS (open circle) or formulated in CRLI005 (solid circle). PBMC were collected at time points as defined in the legend to Figure 2 and assayed against recombinant PfCSP, PfLSAI, PfAMAI or PfMSPI protein and PfSSP2/TRAP peptide pools by IFN- $\gamma$ ELIspot. Data represent the magnitude of IFN- $\gamma$ responses specific for PfCSP, PfSSP2/TRAP, PfLSAI, PfAMAI or PfMSPI, for each monkey. 

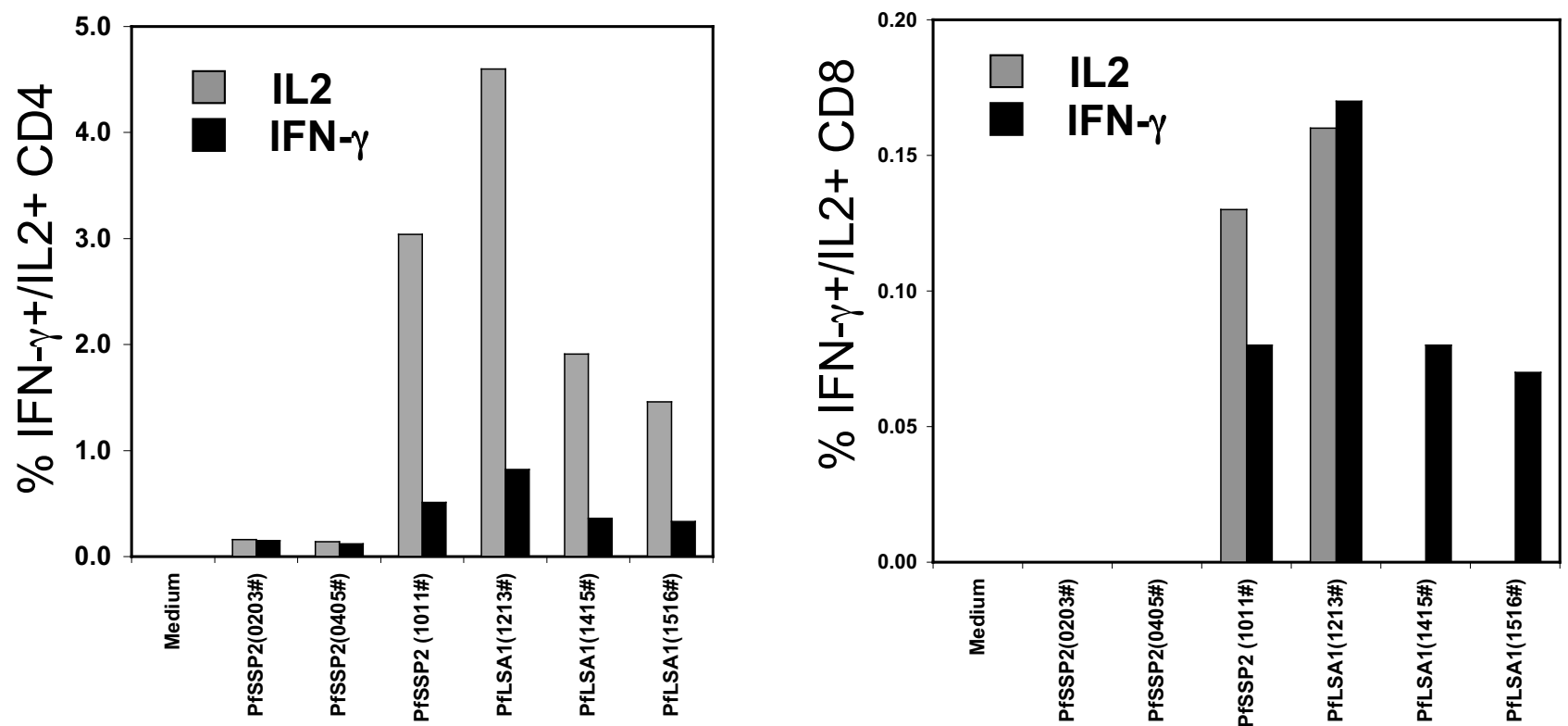

Figure 8

Intracellular IFN- $\gamma$ and IL-2 expression by CD4+ or CD8+ T cells. PBMC from monkey R immunized with CSLAM/PBS, collected at preimmunization and 4 weeks post virus boost time points, were assayed against PfSSP2/TRAP, or PfLSAI peptide pools by intracellular cytokine staining. Data represent the percentage of CD4+ or CD8+ IFN- $\gamma$ and IL-2 producing T cells. Note differences in the $y$-axis scales between CD4+ and CD8+ responses.

phase of the erythrocytic stage of the life cycle (PfAMA1 and PfMSP1). There is evidence that all of these antigens contribute to the immunity of irradiated sporozoite immunized volunteers or naturally acquired immunity, and immunization with each, or with its murine/primate malaria ortholog, has induced some degree of protection in various animal models and, in the case of PfCSP, in humans. Herein, the general safety and immunogenicity of this pentavalent CSLAM vaccine cocktail has been evaluated in rhesus monkeys. Animals were primed with PfCSP plasmid DNA or CSLAM plasmid DNA vaccines in PBS or formulated with CRL1005, and boosted with ALVAC-Pf7. Cell-mediated immune responses were evaluated by IFN- $\gamma$ ELIspot and intracellular cytokine staining, using recombinant proteins and pools of overlapping synthetic peptides. Antigen-specific and parasite-specific antibody responses were evaluated by ELISA and IFAT, respectively.

Antigen-specific IFN- $\gamma$ ELIspot and ELISA responses were detected to all CSLAM antigen components following immunization with either DNA/PBS or DNA/CRL1005. No antigen interference was observed for the frequency or magnitude of $P f C S P$-specific $T$ cell or antibody responses in animals receiving CSLAM as compared to PfCSP alone. On the contrary, a trend of enhanced T cell and antibody responses to PfCSP was noted in the CSLAM immunized animals. These data support the down-selection of the CSLAM antigen combination, contrasting with previous results of multi-antigen plasmid DNA mixtures in vitro and in vivo in mice [18] and humans [16]. These data suggest that further preclinical and clinical evaluation of CSLAM based vaccines is warranted.

It is noteworthy that this CSLAM antigen combination comprises antigens from both pre-erythrocytic $(n=3)$ and erythrocytic $(\mathrm{n}=2)$ stages of the Plasmodium parasite life cycle. Thus, studies also demonstrate the potential for a multi-stage multi-immune response vaccine. The well established dichotomy of the immune system, whereby induction of robust $\mathrm{T}$ cell responses may be compromised by the simultaneous induction of robust antibody responses, and vice versa [66] previously has been a concern.

Amongst the five antigen components of CSLAM, PfAMA1 appeared to be the most immunogenic, as evidenced by the frequency and magnitude of antigen specific $T$ cell and antibody responses. PfAMA1 is an antigen expressed by the blood-stage merozoite (in the micronemes and at the surface of the merozoite) [20] and pre-erythrocytic (liver) [67] stages. It is a primary candidate for a blood stage malaria vaccine designed to induce PfAMA1 specific antibody responses $[68,69]$. However, to date, AMA1-specific 
$\mathrm{T}$ cell responses have been poorly characterized. These data suggest that PfAMA1 should be considered as a prime candidate antigen also for vaccines designed to induce $\mathrm{T}$ cell responses, or both antibody and $\mathrm{T}$ cell responses.

Antigen-specific cellular immune responses, as measured by the IFN- $\gamma$ ELIspot, were detected as early as 4 weeks after the first DNA immunization in nearly half of the monkeys, regardless of the immunogen. The data also indicated that DNA induced T cell responses appear earlier than antibodies, since $\mathrm{T}$ cell responses to most antigens assayed could be detected after a single DNA immunization, whereas antibody responses were detected only after three doses of DNA and then only to some of the antigens. This report represents the first demonstration that $P$. falciparum antigen-specific T cell response can be induced in rhesus monkeys after single dose of plasmid DNA, and one of the few reports of the immunogenicity of a single dose of plasmid DNA in any system [70]. In previous studies in rhesus monkeys, the earliest time point at which $P$. falciparum specific T cell responses could be detected was three weeks after two DNA immunizations (500 $\mu \mathrm{g} /$ antigen/dose), where CTL responses against PfCSP, PfLSA1, PfExp1, and PfLSA1 were detected [37]. In humans, PfCSP-specific CD8+ CTL responses could be detected in 0/5 and 2/5 volunteers immunized with 500 $\mu \mathrm{g}$ PfCSP DNA at 2 wks after the $2^{\text {nd }}$ or 3 rd immunization, respectively; and in 4/5 and 2/4 volunteers immunized with $2500 \mu \mathrm{g}$ PfCSP DNA at 2 wks after either the $2^{\text {nd }}$ or $3^{\text {rd }}$ immunization [40]. IFN- $\gamma$ ELIspot responses could be detected in 14/31 volunteers immunized with 3 doses of $500 \mu \mathrm{g}$ PfCSP DNA (as part of a 5-plasmid mixture of PfCSP, PfSSP2/TRAP, PfLSA1, PfLSA3 and PfExp1) [16] and in $9 / 14$ volunteers after either the $2^{\text {nd }}$ or $3^{\text {rd }}$ immunization with $2500 \mu \mathrm{g}$ PfCSP DNA [41].

In previous studies in the $P$. knowlesi/rhesus model, no T cell responses could be detected to any of four $P$. knowlesi antigens (PkCSP, PkSSP2, PkAMA1, PkMSP1) by IFN- $\gamma$ ELIspot even after three doses of plasmid DNA [38,39]. This may relate to differences in antigen processing and presentation and/or host factors. In the SIV/rhesus nonhuman primate model, $\mathrm{T}$ cell responses were reported in some of the monkeys after the $2^{\text {nd }}$ DNA immunization but in most after the $3^{\text {rd }}$ dose [71], whereas antibody responses could be detected after one dose of DNA [72]. In cynomolgus monkeys, Ebola antigen-specific antibody responses were detected after the $3^{\text {rd }}$ DNA immunization but $\mathrm{T}$ cell proliferation was not detected until after a virus boost $[73,74]$.

First generation DNA vaccines on their own, administered in PBS, have proved to be suboptimal in several nonhuman primate models and human clinical trials, highlighting the need for more effective immune enhance- ment strategies for plasmid DNA vaccines [45-48,75]. Data in the $P$. falciparum/rhesus non-human primate model reported here show that CRL1005 formulation had no apparent effect on vaccine-induced $\mathrm{T}$ cell responses or antibody responses, either before or after viral boost. A similar outcome was noted in mice (M. Sedegah, in preparation). These data contrast with results in other systems, where CRL1005 formulation of inactivated viral vaccines [50], recombinant protein vaccines $[51,53]$ or plasmid DNA vaccines $[49,54]$ resulted in a substantial enhancement of antigen-specific immune responses. In a CMV mouse immunogenicity model, CRL1005 provided restoration of both antibody and IFN- $\gamma$ ELIspot responses in a multivalent vaccine [49]. It is unclear why CRL1005 does not have a detectable effect or restoration in the malaria model, but it is possible that the effect could be antigen dependent.

The studies also provided preliminary information on the effector cells and cytokines preferentially induced in the Plasmodium rhesus model by DNA prime/virus boost immunization. Data indicated that CD4+IL-2+ responses were more predominant than CD8+ T cell responses. This contrasts with results of comprehensive studies in murine models identifying CD8+ IFN- $\gamma$ as the predominant immune effector mechanism in irradiated sporozoite and plasmid DNA vaccine induced protection [76-80]. Since these data have important implications with regard to the relevance of the rhesus Macaca mulatta model for evaluation of Plasmodium vaccines $[81,82]$, additional studies are necessary to elucidate the Plasmodium vaccine-induced immune effector mechanisms in rhesus. It is important to note, however, that the results show that Plasmodium antigen specific CD8+ IFN- $\gamma$ responses were detected in rhesus only in the presence of detectable CD4+ T cell responses, consistent with the profile of $\mathrm{CD} 4+\mathrm{T}$ cell dependent CD8+ Type 1 responses observed in malaria DNA vaccine studies in humans as measured by $\mathrm{T}$ cell depletion and enrichment ELIspot assays and RT-PCR [44,41,40]. It has been proposed [41] that CD4+ T cells function in a bystander helper capacity for $\mathrm{CD} 8+\mathrm{T}$ cell production of IFN- $\gamma$.

In summary, the immunogenicity of the CSLAM pentavalent pre-erythrocytic and erythrocytic stage antigen combination has been established in rhesus monkeys by the induction of both $\mathrm{T}$ cell and antibody responses to each antigen component of the multi-antigen mixture in the apparent absence of antigen interference. The two most immunogenic antigens of those tested were PfAMA1 and PfSSP2/TRAP. Using conventional measures of antibody and T-cell responses, CRL1005 formulation does not enhance the immunogenicity of plasmid DNA vaccines, in the rhesus non-human primate model of malaria. The presented studies also demonstrate general safety and the 
potential for multi-valent multi-stage and multi-immune response $P f$ vaccines based on rational antigen selection and combination. These results suggest that clinical evaluation of the CSLAM antigen combination is warranted, but that further formulation development to increase the immunogenicity of DNA encoded antigens may be required before proceeding to the clinic with DNA-based vaccines against malaria.

\section{Abbreviations}

CSLAM: PfCSP, PfSSP2/TRAP, PfLSA1, PfAMA1 and PfMSP1-42; ELISA, enzyme-linked immunosorbent assay; IFAT, indirect fluorescent-antibody test; Pf, Plasmodium falciparum.

\section{Authors' contributions}

DLD, DCK and DJC, conceived and designed the study, and contributed to the supervision and execution of the research. DLD and GJ wrote the manuscript. GJ was responsible for, and participated in, the execution of the $\mathrm{T}$ cell immunology assays. YC was responsible for the execution of the antibody assays. MFB, GB, NR, HG, SA and VF performed the immunology assays. NBP facilitated the transfer and acquisition of reagents and samples and assisted in project coordination and management. MRG, $\mathrm{AM}, \mathrm{ES}$, and IC were responsible for the execution of the nonhuman primate studies. AG and DCK were responsible for the provision and formulation of CRL1005. DEL, AS, and LBM provided reagents for assay. CRM assisted with statistical analysis. KG assisted with construction of the vaccines. WRW assisted with vaccine preparation and sample processing. All authors read and approved the manuscript before submission.

\section{Additional material}

\section{Additional file 1}

Effects of CRL1005 formulation on the magnitude of antibody responses in (A) PfCSP/PBS versus PfCSP/CRL1005 or (B) CSLAM/PBS versus CSLAM/CRL1005 immunized monkeys. Monkeys were immunized with either PfCSP or CSLAM in PBS (open circles) or formulated in CRL1005 (solid circles). Sera from immunized monkeys were assayed against PfCSP, PfSSP2/TRAP, PfLSA1, PfAMA1 or PfMSP1 capture antigens by ELISA. Data are presented as the geometric means of titers at OD 0.5 units from individual monkeys per group. ELISA responses were classified as positive if (1) OD0.5 unit titer was > 10; and (2) the seroconversion index (ratio of titer post-immunization to titer pre-immunization) was > 4. Preimmun $=$ preimmunization; $4 w k s D N A \_1=4$ wks post $1^{\text {st }} D N A$ immunization; $4 w k s D N A \_2=4$ wks post $2^{\text {nd }}$ DNA immunization; $4 w k s D N A \quad 3=4$ wks post $3^{\text {rd }}$ DNA immunization; 4 wkvirus $=4 \mathrm{wks}$ post ALVAC-Pf7 boost; 12 wksVirus $=12$ wks post ALVAC-Pf7 boost. Click here for file

[http://www.biomedcentral.com/content/supplementary/14752875-6-135-S1.pdf]

\section{Acknowledgements}

This work was supported by funds allocated to the Naval Medical Research Center by the US Army Medical Research Materiel Command (work unit 6II53NM458.SI8.A0242). The experiments reported herein were conducted incompliance with the Animal Welfare Act and in accordance with the principles set forth in the "Guide for the Care and Use of Laboratory Animals," Institute of Laboratory Animal Resources, National Research Council, National Academy Press, 1996. The views expressed in this article are those of the authors and do not necessarily reflect the official policy or position of the Department of the Navy, Department of Defense, nor the U.S. Government.

\section{References}

I. WHO: World Malaria Report 2005. 2005 [http://rbm.who.int/ wmr2005/index.html].

2. Gallup JL, Sachs JD: The economic burden of malaria. Am J Trop Med Hyg 200I, 64( I-2 Suppl):85-96.

3. Girard MP, Reed ZH, Friede M, Kieny MP: A review of human vaccine research and development: malaria. Vaccine 2007, 25(9): I567- 1580.

4. Clyde DF, McCarthy VC, Miller RM, Hornick RB: Specificity of protection of man immunized against sporozoite-induced falciparum malaria. Am J Med Sci 1973, 266(6):398-403.

5. Hoffman SL, Goh LM, Luke TC, Schneider I, Le TP, Doolan DL, Sacci J, de la Vega P, Dowler M, Paul C, Gordon DM, Stoute JA, Church LW, Sedegah M, Heppner DG, Ballou WR, Richie TL: Protection of humans against malaria by immunization with radiationattenuated Plasmodium falciparum sporozoites. J Infect Dis 2002, I85(8): I I55-II64.

6. Nussenzweig RS, Vanderberg J, Most H, Orton C: Protective immunity produced by the injection of $\mathrm{x}$-irradiated sporozoites of plasmodium berghei. Nature 1967, 216(III): I60-162.

7. Gwadz RW, Cochrane AH, Nussenzweig V, Nussenzweig RS: Preliminary studies on vaccination of rhesus monkeys with irradiated sporozoites of Plasmodium knowlesi and characterization of surface antigens of these parasites. Bull World Health Organ 1979, 57 Suppl I: 165-173.

8. Baird JK: Age-dependent characteristics of protection v. susceptibility to Plasmodium falciparum. Ann Trop Med Parasitol 1998, 92(4):367-390.

9. Good MF, Doolan DL: Immune effector mechanisms in malaria. Curr Opin Immunol 1999, I I(4):412-419.

10. Plebanski M, Hill AV: The immunology of malaria infection. Curr Opin Immunol 2000, I 2(4):437-44I.

II. Doolan DL, Martinez-Alier N: Immune response to pre-erythrocytic stages of malaria parasites. Curr Mol Med 2006, 6(2): 169-185.

12. Cohen S, Mc Gl, Carrington S: Gamma-globulin and acquired immunity to human malaria. Nature 1961, 192:733-737.

13. Perlmann P, Troye-Blomberg M: Malaria blood-stage infection and its control by the immune system. Folia Biol (Praha) 2000, 46(6):210-218.

14. Yazdani SS, Mukherjee P, Chauhan VS, Chitnis CE: Immune responses to asexual blood-stages of malaria parasites. Curr Mol Med 2006, 6(2):187-203.

15. Doolan DL, Hoffman SL: DNA-based vaccines against malaria: status and promise of the Multi-Stage Malaria DNA Vaccine Operation. Int J Parasitol 200I, 3 I (8):753-762.

16. Wang R, Richie TL, Baraceros MF, Rahardjo N, Gay T, Banania JG, Charoenvit Y, Epstein JE, Luke T, Freilich DA, Norman J, Hoffman SL: Boosting of DNA vaccine-elicited gamma interferon responses in humans by exposure to malaria parasites. Infect Immun 2005, 73(5):2863-2872.

17. Walsh DS, Pichyangkul S, Gettayacamin M, Tongtawe P, Siegrist CA, Hansukjariya P, Kester KE, Holland CA, Voss G, Cohen J, Stewart AV, Miller RS, Ballou WR, Heppner DG Jr.: Safety and immunogenicity of rts,s+trap malaria vaccine, formulated in the as $02 a$ adjuvant system, in infant rhesus monkeys. Am J Trop Med Hyg 2004, 70(5):499-509.

18. Sedegah M, Charoenvit $Y$, Minh L, Belmonte M, Majam VF, Abot S, Ganeshan H, Kumar S, Bacon DJ, Stowers A, Narum DL, Carucci DJ, Rogers WO: Reduced immunogenicity of DNA vaccine plasmids in mixtures. Gene Ther 2004, I I (5):448-456. 
19. Bacon DJ, Sedegah M: Reduced production of RNA transcripts from individual DNA plasmids given in a multivalent DNA vaccine formula. Hum Vaccin 2007, 3(2):48-53.

20. Ellis J, Ozaki LS, Gwadz RW, Cochrane AH, Nussenzweig V, Nussenzweig RS, Godson GN: Cloning and expression in E. coli of the malarial sporozoite surface antigen gene from Plasmodium knowlesi. Nature 1983, 302(5908):536-538.

21. Campbell JR: DNA sequence of the gene encoding a Plasmodium falciparum malaria candidate vaccine antigen. Nucleic Acids Res 1989, 17(14):5854.

22. Robson KJ, Hall JR, Jennings MW, Harris TJ, Marsh K, Newbold Cl, Tate VE, Weatherall DJ: A highly conserved amino-acid sequence in thrombospondin, properdin and in proteins from sporozoites and blood stages of a human malaria parasite. Nature 1988, 335(6|85):79-82.

23. Rogers WO, Malik A, Mellouk S, Nakamura K, Rogers MD, Szarfman A, Gordon DM, Nussler AK, Aikawa M, Hoffman SL: Characterization of Plasmodium falciparum sporozoite surface protein 2. Proc Natl Acad Sci U S A 1992, 89(19):9176-9180.

24. Guerin-Marchand C, Druilhe P, Galey B, Londono A, Patarapotikul J, Beaudoin RL, Dubeaux C, Tartar A, Mercereau-Puijalon O, Langsley G: A liver-stage-specific antigen of Plasmodium falciparum characterized by gene cloning. Nature 1987, 329(6 135): 164-167.

25. Zhu J, Hollingdale MR: Structure of Plasmodium falciparum liver stage antigen-I. Mol Biochem Parasitol I99I, 48(2):223-226.

26. Deans JA, Thomas AW, Cohen S: Stage-specific protein synthesis by asexual blood stage parasites of Plasmodium knowlesi. Mol Biochem Parasitol I 983, 8(I):3 I-44.

27. Marshall VM, Zhang L, Anders RF, Coppel RL: Diversity of the vaccine candidate AMA-I of Plasmodium falciparum. Mol Biochem Parasitol 1996, 77(1):109-II3.

28. Holder AA, Freeman RR: Immunization against blood-stage rodent malaria using purified parasite antigens. Nature 1981, 294(5839):36I-364.

29. Pan W, Tolle R, Bujard $H$ : A direct and rapid sequencing strategy for the Plasmodium falciparum antigen gene gp/90/ MSAI. Mol Biochem Parasitol 1995, 73(I-2):24I-244.

30. Costa SM, Paes MV, Barreto DF, Pinhao AT, Barth OM, Queiroz JL, Armoa GR, Freire MS, Alves AM: Protection against dengue type 2 virus induced in mice immunized with a DNA plasmid encoding the non-structural I (NSI) gene fused to the tissue plasminogen activator signal sequence. Vaccine 2006, 24(2): 195-205.

31. Kaslow DC: A potential disruptive technology in vaccine development: gene-based vaccines and their application to infectious diseases. Trans $R$ Soc Trop Med Hyg 2004, 98(I0):593-60I.

32. Ulmer JB, Wahren B, Liu MA: Gene-based vaccines: recent technical and clinical advances. Trends Mol Med 2006, I 2(5):2 I 6-222.

33. Sedegah M, Hedstrom R, Hobart P, Hoffman SL: Protection against malaria by immunization with plasmid DNA encoding circumsporozoite protein. Proc Natl Acad Sci U S A 1994, 9 I(2I):9866-9870.

34. Sedegah M, Jones TR, Kaur M, Hedstrom R, Hobart P, Tine JA, Hoffman SL: Boosting with recombinant vaccinia increases immunogenicity and protective efficacy of malaria DNA vaccine. Proc Natl Acad Sci U S A 1998, 95( (13):7648-7653.

35. Sedegah M, Weiss W, Sacci JB Jr., Charoenvit Y, Hedstrom R, Gowda K, Majam VF, Tine J, Kumar S, Hobart P, Hoffman SL: Improving protective immunity induced by DNA-based immunization: priming with antigen and GM-CSF-encoding plasmid DNA and boosting with antigen-expressing recombinant poxvirus. J Immunol 2000, I 64(I I):5905-59|2.

36. Doolan DL, Sedegah M, Hedstrom RC, Hobart $P$, Charoenvit $Y$, Hoffman SL: Circumventing genetic restriction of protection against malaria with multigene DNA immunization: CD8+ cell-, interferon gamma-, and nitric oxide-dependent immunity. J Exp Med 1996, I83(4): 1739-1746.

37. Wang R, Doolan DL, Charoenvit Y, Hedstrom RC, Gardner MJ, Hobart P, Tine J, Sedegah M, Fallarme V, Sacci JB Jr., Kaur M, Klinman DM, Hoffman SL, Weiss WR: Simultaneous induction of multiple antigen-specific cytotoxic $T$ lymphocytes in nonhuman primates by immunization with a mixture of four Plasmodium falciparum DNA plasmids. Infect Immun 1998, 66(9):4193-4202.
38. Rogers WO, Baird JK, Kumar A, Tine JA, Weiss W, Aguiar JC, Gowda K, Gwadz R, Kumar S, Gold M, Hoffman SL: Multistage multiantigen heterologous prime boost vaccine for Plasmodium knowlesi malaria provides partial protection in rhesus macaques. Infect Immun 200I, 69(9):5565-5572.

39. Rogers WO, Weiss WR, Kumar A, Aguiar JC, Tine JA, Gwadz R, Harre JG, Gowda K, Rathore D, Kumar S, Hoffman SL: Protection of rhesus macaques against lethal Plasmodium knowlesi malaria by a heterologous DNA priming and poxvirus boosting immunization regimen. Infect Immun 2002, 70(8):4329-4335.

40. Wang R, Epstein J, Baraceros FM, Gorak EJ, Charoenvit Y, Carucci DJ, Hedstrom RC, Rahardjo N, Gay T, Hobart P, Stout R, Jones TR, Richie TL, Parker SE, Doolan DL, Norman J, Hoffman SL: Induction of CD4(+) T cell-dependent CD8(+) type I responses in humans by a malaria DNA vaccine. Proc Natl Acad Sci U S A 200 I, 98(19): 10817-10822.

4I. Wang R, Doolan DL, Le TP, Hedstrom RC, Coonan KM, Charoenvit Y, Jones TR, Hobart P, Margalith M, Ng J, Weiss WR, Sedegah M, de Taisne C, Norman JA, Hoffman SL: Induction of antigen-specific cytotoxic T lymphocytes in humans by a malaria DNA vaccine. Science 1998, 282(5388):476-480.

42. Le TP, Coonan KM, Hedstrom RC, Charoenvit Y, Sedegah M, Epstein JE, Kumar S, Wang R, Doolan DL, Maguire JD, Parker SE, Hobart P, Norman J, Hoffman SL: Safety, tolerability and humoral immune responses after intramuscular administration of a malaria DNA vaccine to healthy adult volunteers. Vaccine 2000, 18(18): 1893-1901.

43. Epstein JE, Gorak EJ, Charoenvit Y, Wang R, Freydberg N, Osinowo O, Richie TL, Stoltz EL, Trespalacios F, Nerges J, Ng J, Fallarme-Majam V, Abot E, Goh L, Parker S, Kumar S, Hedstrom RC, Norman J, Stout R, Hoffman SL: Safety, tolerability, and lack of antibody responses after administration of a PfCSP DNA malaria vaccine via needle or needle-free jet injection, and comparison of intramuscular and combination intramuscular/intradermal routes. Hum Gene Ther 2002, I3(13): I55 I-1560.

44. Wang R, Epstein J, Charoenvit Y, Baraceros FM, Rahardjo N, Gay T, Banania JG, Chattopadhyay R, de la Vega P, Richie TL, Tornieporth N, Doolan DL, Kester KE, Heppner DG, Norman J, Carucci DJ, Cohen JD, Hoffman SL: Induction in humans of CD8+ and CD4+ T cell and antibody responses by sequential immunization with malaria DNA and recombinant protein. J Immunol 2004, I 72(9):556|-5569.

45. Lemieux $P$ : Technological advances to increase immunogenicity of DNA vaccines. Expert Rev Vaccines 2002, I (I):85-93.

46. Woodland $\mathrm{DL}$ : Jump-starting the immune system: primeboosting comes of age. Trends Immunol 2004, 25(2):98-104.

47. Moore AC, Hill AV: Progress in DNA-based heterologous prime-boost immunization strategies for malaria. Immunol Rev 2004, 199:126-143.

48. Donnelly JJ, Wahren $B$, Liu MA: DNA vaccines: progress and challenges. J Immunol 2005, I 75(2):633-639.

49. Selinsky C LC Wloch M, Geall A, Hermanson G, Kaslow D,: A DNAbased vaccine for the prevention of human cytomegalovirusassociated disease. Human Vaccines 2005, I(I):16-23.

50. Newman MJ, Actor JK, Balusubramanian M, Jagannath C: Use of nonionic block copolymers in vaccines and therapeutics. Crit Rev Ther Drug Carrier Syst 1998, I 5(2):89-142.

5I. Evans RK, Zhu DM, Casimiro DR, Nawrocki DK, Mach H, Troutman RD, Tang A, Wu S, Chin S, Ahn C, Isopi LA, Williams DM, Xu Z, Shiver JW, Volkin DB: Characterization and biological evaluation of a microparticle adjuvant formulation for plasmid DNA vaccines. J Pharm Sci 2004, 93(7): 1924-1939.

52. Todd CW, Pozzi LA, Guarnaccia JR, Balasubramanian M, Henk WG, Younger LE, Newman MJ: Development of an adjuvant-active nonionic block copolymer for use in oil-free subunit vaccines formulations. Vaccine 1997, 15(5):564-570.

53. Casimiro DR, Chen L, Fu TM, Evans RK, Caulfield MJ, Davies ME, Tang A, Chen M, Huang L, Harris V, Freed DC, Wilson KA, Dubey S, Zhu DM, Nawrocki D, Mach H, Troutman R, Isopi L, Williams D, Hurni W, Xu Z, Smith JG, Wang S, Liu X, Guan L, Long R, Trigona W, Heidecker GJ, Perry HC, Persaud N, Toner TJ, Su Q, Liang X, Youil R, Chastain M, Bett AJ, Volkin DB, Emini EA, Shiver JW: Comparative immunogenicity in rhesus monkeys of DNA plasmid, recombinant vaccinia virus, and replication-defective adenovirus vectors expressing a human immunodeficiency virus type I gag gene. J Virol 2003, 77(II):6305-63I3. 
54. Katz JM, Lu X, Todd CW, Newman MJ: A nonionic block co-polymer adjuvant (CRLI 005) enhances the immunogenicity and protective efficacy of inactivated influenza vaccine in young and aged mice. Vaccine 2000, 18(2I):2I77-2I 87.

55. Newman MJ: Heterologous prime-boost vaccination strategies for HIV-I: augmenting cellular immune responses. Curr Opin Investig Drugs 2002, 3(3):374-378.

56. Breathnach CC, Clark HJ, Clark RC, Olsen CW, Townsend HG, Lunn DP: Immunization with recombinant modified vaccinia Ankara (rMVA) constructs encoding the HA or NP gene protects ponies from equine influenza virus challenge. Vaccine 2006, 24(8): II80-II90.

57. Skeiky YA, Sadoff JC: Advances in tuberculosis vaccine strategies. Nat Rev Microbiol 2006, 4(6):469-476.

58. Luke C], Carner K, Liang X, Barbour AG: An OspA-based DNA vaccine protects mice against infection with Borrelia burgdorferi. J Infect Dis 1997, 175(I):91-97.

59. Narum DL, Kumar S, Rogers WO, Fuhrmann SR, Liang H, Oakley M, Taye A, Sim BK, Hoffman SL: Codon optimization of gene fragments encoding Plasmodium falciparum merzoite proteins enhances DNA vaccine protein expression and immunogenicity in mice. Infect Immun 200I, 69(1 2):7250-7253.

60. Kolodny N, Kitov S, Vassell MA, Miller VL, Ware LA, Fegeding K, De La Vega P, Sacci JB Jr., Lanar DE: Two-step chromatographic purification of recombinant Plasmodium falciparum circumsporozoite protein from Escherichia coli. J Chromatogr B Biomed Sci Appl 200I, 762(I):77-86.

61. Dutta S, Lalitha PV, Ware LA, Barbosa A, Moch JK, Vassell MA, Fileta BB, Kitov S, Kolodny N, Heppner DG, Haynes JD, Lanar DE: Purification, characterization, and immunogenicity of the refolded ectodomain of the Plasmodium falciparum apical membrane antigen I expressed in Escherichia coli. Infect Immun 2002, 70(6):3I0I-3IIO.

62. Kumar A, Weiss W, Tine JA, Hoffman SL, Rogers WO: ELISPOT assay for detection of peptide specific interferon-gamma secreting cells in rhesus macaques. I Immunol Methods 200I, 247(I-2):49-60.

63. Charoenvit Y, Leef MF, Yuan LF, Sedegah M, Beaudoin RL: Characterization of Plasmodium yoelii monoclonal antibodies directed against stage-specific sporozoite antigens. Infect Immun 1987, 55(3):604-608.

64. Charoenvit $Y$, Mellouk S, Cole C, Bechara R, Leef MF, Sedegah M, Yuan LF, Robey FA, Beaudoin RL, Hoffman SL: Monoclonal, but not polyclonal, antibodies protect against Plasmodium yoelii sporozoites. J Immunol I99I, 146(3): I020-1025.

65. Good MF, Berzofsky JA, Maloy WL, Hayashi Y, Fujii N, Hockmeyer WT, Miller LH: Genetic control of the immune response in mice to a Plasmodium falciparum sporozoite vaccine. Widespread nonresponsiveness to single malaria $T$ epitope in highly repetitive vaccine. J Exp Med 1986, 164(2):655-660.

66. Bottomly K: A functional dichotomy in CD4+ T lymphocytes. Immunol Today 1988, 9(9):268-274.

67. Bodescot M, Silvie O, Siau A, Refour P, Pino P, Franetich JF, Hannoun $L$, Sauerwein R, Mazier D: Transcription status of vaccine candidate genes of Plasmodium falciparum during the hepatic phase of its life cycle. Parasitol Res 2004, 92(6):449-452.

68. Malkin EM, Diemert DJ, McArthur JH, Perreault JR, Miles AP, Giersing BK, Mullen GE, Orcutt A, Muratova O, Awkal M, Zhou H, Wang J, Stowers A, Long CA, Mahanty S, Miller LH, Saul A, Durbin AP: Phase I clinical trial of apical membrane antigen I: an asexual blood-stage vaccine for Plasmodium falciparum malaria. Infect Immun 2005, 73(6):3677-3685.

69. Saul A, Lawrence G, Allworth A, Elliott S, Anderson K, Rzepczyk C, Martin LB, Taylor D, Eisen DP, Irving DO, Pye D, Crewther PE, Hod$\operatorname{der}$ AN, Murphy VJ, Anders RF: A human phase I vaccine clinical trial of the Plasmodium falciparum malaria vaccine candidate apical membrane antigen $I$ in Montanide ISA720 adjuvant. Vaccine 2005, 23(23):3076-3083.

70. Amara RR, Villinger F, Altman JD, Lydy SL, O'Neil SP, Staprans SI, Montefiori DC, Xu Y, Herndon JG, Wyatt LS, Candido MA, Kozyr NL, Earl PL, Smith JM, Ma HL, Grimm BD, Hulsey ML, Miller J, McClure HM, McNicholl JM, Moss B, Robinson HL: Control of a mucosal challenge and prevention of AIDS by a multiprotein DNA/MVA vaccine. Science 200I, 292(55 I4):69-74.

71. Shiver JW, Fu TM, Chen L, Casimiro DR, Davies ME, Evans RK, Zhang ZQ, Simon AJ, Trigona WL, Dubey SA, Huang L, Harris VA, Long RS,
Liang X, Handt L, Schleif WA, Zhu L, Freed DC, Persaud NV, Guan L, Punt KS, Tang A, Chen M, Wilson KA, Collins KB, Heidecker GJ, Fernandez VR, Perry HC, Joyce JG, Grimm KM, Cook JC, Keller PM, Kresock DS, Mach H, Troutman RD, Isopi LA, Williams DM, Xu Z, Bohannon KE, Volkin DB, Montefiori DC, Miura A, Krivulka GR, Lifton MA, Kuroda MJ, Schmitz JE, Letvin NL, Caulfield MJ, Bett AJ, Youil R, Kaslow DC, Emini EA: Replication-incompetent adenoviral vaccine vector elicits effective anti-immunodeficiencyvirus immunity. Nature 2002, 4I 5(6869):33I-335

72. Vinner L, Wee EG, Patel S, Corbet S, Gao GP, Nielsen C, Wilson JM, Ertl HC, Hanke T, Fomsgaard A: Immunogenicity in Mamu-A*0 I rhesus macaques of a CCR5-tropic human immunodeficiency virus type I envelope from the primary isolate $(\mathrm{B} \times 08)$ after synthetic DNA prime and recombinant adenovirus 5 boost. J Gen Virol 2003, 84(Pt I):203-2 I3.

73. Sullivan NJ, Sanchez A, Rollin PE, Yang ZY, Nabel GJ: Development of a preventive vaccine for Ebola virus infection in primates. Nature 2000, 408(68 I 2):605-609.

74. Sullivan NJ, Geisbert TW, Geisbert JB, Xu L, Yang ZY, Roederer M, Koup RA, Jahrling PB, Nabel G]: Accelerated vaccination for Ebola virus haemorrhagic fever in non-human primates. Nature 2003, 424(6949):681-684.

75. Manoj S, Babiuk LA, van Drunen Littel-van den Hurk S: Approaches to enhance the efficacy of DNA vaccines. Crit Rev Clin Lab Sci 2004, 4 I (I): I-39.

76. Weiss WR, Sedegah M, Beaudoin RL, Miller LH, Good MF: CD8+ T cells (cytotoxic/suppressors) are required for protection in mice immunized with malaria sporozoites. Proc Natl Acad Sci U S A 1988, 85(2):573-576.

77. Seguin MC, Klotz FW, Schneider I, Weir JP, Goodbary M, Slayter M, Raney J], Aniagolu JU, Green SJ: Induction of nitric oxide synthase protects against malaria in mice exposed to irradiated Plasmodium berghei infected mosquitoes: involvement of interferon gamma and CD8+ $\mathbf{T}$ cells. J Exp Med 1994, 180(I):353-358.

78. Doolan DL, Hoffman SL: The complexity of protective immunity against liver-stage malaria. I Immunol 2000, 165(3): : 1453-1462.

79. Hoffman SL, Doolan DL: Malaria vaccines-targeting infected hepatocytes. Nat Med 2000, 6(I I):1218-1219.

80. Doolan DL, Hoffman SL: IL- 12 and NK cells are required for antigen-specific adaptive immunity against malaria initiated by CD8+ T cells in the Plasmodium yoelii model. J Immunol 1999, 163(2):884-892.

81. Stowers AW, Miller LH: Are trials in New World monkeys on the critical path for blood-stage malaria vaccine development? Trends Parasitol 200I, I7(9):415-419.

82. Heppner DG, Cummings JF, Ockenhouse C, Kester KE, Lyon JA, Gordon DM: New World monkey efficacy trials for malaria vaccine development: critical path or detour? Trends Parasitol 200I, I7(9):419-425.
Publish with BioMed Central and every scientist can read your work free of charge

"BioMed Central will be the most significant development for disseminating the results of biomedical research in our lifetime. "

Sir Paul Nurse, Cancer Research UK

Your research papers will be:

- available free of charge to the entire biomedical community

- peer reviewed and published immediately upon acceptance

- cited in PubMed and archived on PubMed Central

- yours - you keep the copyright

Submit your manuscript here:

http://www.biomedcentral.com/info/publishing_adv.asp
BiolMedcentral 